Western University Scholarship@Western

Brescia School of Leadership \& Social Change

Publications

School of Leadership \& Social Change

2019

\title{
Invisible or Clichéd: How are Women Represented in Business Cases?
}

Colleen M. Sharen

Brescia University College, csharen@uwo.ca

Rosemary A. McGowan

Wilfrid Laurier University, mcgowan@wlu.ca

Follow this and additional works at: https://ir.lib.uwo.ca/brescialeadershipsocialchangepub

Part of the Business Commons, and the Higher Education Commons

Citation of this paper:

Sharen, Colleen M. and McGowan, Rosemary A., "Invisible or Clichéd: How are Women Represented in Business Cases?" (2019). Brescia School of Leadership \& Social Change Publications. 1.

https://ir.lib.uwo.ca/brescialeadershipsocialchangepub/1 
Invisible or Clichéd: How Are Women Represented in Business Cases?

\author{
Colleen M. Sharen \\ Brescia University College \\ Rosemary A. McGowan \\ Wilfrid Laurier University
}

\begin{abstract}
Authors' Note:
Colleen M. Sharen, School of Leadership and Social Change, Brescia University College; Rosemary A. McGowan, Lazaridis School of Business \& Economics, Wilfrid Laurier University.

Correspondence concerning this article should be addressed to Colleen Sharen, School of Leadership and Social Change, Brescia University College, 1285 Western Road, London, ON N6G 1H2. Email: csharen@uwo.ca
\end{abstract}


Invisible or Clichéd: How Are Women Represented in Business Cases?

\begin{abstract}
Women represent just under $50 \%$ of undergraduate business graduates and $36 \%$ of MBA graduates. Despite their strong presence in management education programs, women are noticeably absent from business case studies - a key pedagogical tool for instruction within management education programs worldwide. While case studies inform students about business processes, decision making, strategy, and leadership and management challenges, they also promote unintentional learning about gender. We argue that case studies contain a "hidden curriculum" that presents and reinforces implicit assumptions and stereotypes about women's fitness to lead. Using NVivo 11 software to analyze the content of written cases, we examine the presence, absence, and representation of female and male protagonists in a sample of business cases published by a large business school case publisher. The findings offer comparative insights into the proportion of cases featuring female protagonists, the representation of women and men in leadership roles, and the characterizations of the female and male protagonists. Women protagonists were absent in over $80 \%$ of cases, and when present, were portrayed as less visionary, risk-taking, agentic, certain, and more emotional, cautious, quality and detail oriented than men.
\end{abstract}

Keywords: business education, business case studies, female and male protagonists, presence, absence, representation 
Invisible or Clichéd: How Are Women Represented in Business Cases?

Women's participation in management education programs has been steadily increasing. The Association to Advance Collegiate Schools of Business (AACSB) reports that women represent $42 \%$ and $46 \%$ of U.S. and Canadian undergraduate management students respectively (AACSB, 2016). In 2015-2016, women received 36\% of MBA degrees conferred in Asia, Oceania, Latin America, and North America, while women earned 45\% of MBA degrees conferred in Europe (Graduate Admission Council, 2017). In U.S. AACSB-accredited schools, the percentage of female full professors increased from $15 \%$ to $20 \%$ and of female associate professors from 26\% to 32\% between 2006/07 and 2015/16 (Brown, 2017). By these metrics, women have experienced real progress in participation in management education.

However, gaps remain. When women leave school and enter the managerial world, the gap begins to widen between men's and women's professional attainment. For every 100 women promoted to their first managerial position, 130 men are promoted; furthermore, women constitute $45 \%$ of entry level professional employees, but only $37 \%$ of managers (Yee et al., 2016). These statistics suggests that management education may not have prepared women for their first managerial positions. Further evidence that management education may be failing our students appears in a study of undergraduate business majors (Paris \& Decker, 2012), which showed that women's associations of female characteristics with effective management declined over their four years of management education, while men did not associate female characteristics with effective management at any point during their education. This study suggests that management education, one critical building block of management competency, may not prepare women for management positions and that it may not foster women's 
development of a professional identity or men's acceptance of women as managers (McLean \& Unter, 2010; Norris \& Wylie, 1995; Paris \& Decker, 2012).

Two events prompted us to focus on the role that business cases play in reinforcing assumptions about men's and women's fitness to lead in management education. In January 2014, the Dean of the Harvard Business School apologized to its alumnae and promised to increase the number of women represented in business cases (Byrne, 2014). Shortly thereafter, Symons and Ibarra (2014) published an analysis of top-selling and prize-winning cases that suggested that women were absent in most cases and when present, they were represented in limited ways and in sex-role stereotyped industries.

We chose to examine cases because, unlike the systematic and cultural factors that influence the implicit assumptions about women's management abilities, the selection of case studies is within the instructor's control. While cases help students learn to conduct analyses, and make decisions and recommendations (Mauffette-Leenders, Erskine, \& Leenders, 2007), they can also create unintended learning about gender roles in organizations. We wondered, do the case studies used in management education transmit stereotyped representations of women's and men's managerial competency? Are women represented in cases differently than or similarly to men? Are women invisible or just clichéd?

\section{Literature Review}

\section{Gender and Management Education}

The primary objective of management education is to prepare students for management (Starkey \& Tempest, 2008). Indeed, completing a management degree is often a precursor to women progressing in management (Roberts \& Karambayya, 2017). Yet, management education programs demonstrate a predominantly masculine institutional culture (Sinclair as cited in Smith, 
1997) that draws on historical assumptions about gender that constrain what men and women can achieve (Williams as cited in Apple \& King, 1983). By extension, the implicit underpinnings of management education are typically associated with hard, masculine characteristics: fewer management education programs incorporate the softer interpersonal and social competencies typically associated with women (Lämsä \& Savela, 2014). Furthermore, management education programs tend to be dominated by male faculty and administrators (Brown, 2016; Drozdowski, 2013), potentially reinforcing these gendered associations.

In response to these perceptions, consensus is emerging that management education programs need to improve the way they prepare women for management roles; for example, in early 2014, Dean Nitin Nohria of the Harvard Business School set a goal to increase the proportion of women protagonists in Harvard cases from $9 \%$ to $20 \%$, to increase the number of women on corporate boards, and to improve mentoring opportunities for women (Byrne, 2014). A short while later, the White House convened a working group of business school deans and government administrators to develop an national inclusiveness strategy for business schools (The White House, 2015). One of the many expressed goals of the group was to increase the proportion of female and minority protagonists in business cases (The White House, 2015). It appears that instructors, administrators, and policy makers believe that cases are an important tool in the development of students' schema of an ideal manager and the creation of their professional identity.

\section{Culture, Professional Identity, and Anticipatory Socialization}

Professional cultures comprise a group's shared learning of what has worked well enough to become the way things are done in that profession (Schein \& Schein, 2017). New members of a profession learn the correct way to think, feel, and behave through a socialization process 
(Schein \& Schein, 2017). Eventually, these implicit assumptions become understood by members of the profession as objective, normative, and value neutral (Bourdieu, 1973). This consensus of beliefs, values, and norms eventually drops out of our awareness, becoming a taken-for-granted set of assumptions about how things work (Schein \& Schein, 2017). In the case of the management profession, people hold implicit leadership theories, assumptions about the traits, behaviors, and values of a typical or effective leader (Junker \& van Dick, 2014), including factors such as sensitivity, dedication, tyranny, charisma, attractiveness, masculinity, intelligence, and strength (Offermann, Kennedy, \& Wirtz, 1994). These assumptions, along with the behaviors, traits, beliefs, and practices expected of a professional manager (Reid, Dahlgren, Petocz, \& Abrandt Dahlgren, 2008) form the core of the managerial professional identity.

\section{Management Education and Cases}

Beliefs about the traits, characteristics, and gender associated with managerial capabilities are shaped, in part, by students' educational experiences. Management education programs develop students' professional identities by socializing students formally and informally through curricular and extra-curricular activities (Caza \& Brower, 2015). The formal curriculum, set by the instructor and administrators, is explicitly associated with learning outcomes and explicitly assessed. In contrast, the informal curriculum, set by instructors and delivered in the classroom, may be associated with a learning outcome but not assessed; or may be assessed but not associated with a learning outcome; or may be taught, but neither associated with a learning outcome nor assessed (Caza \& Brower, 2015). Finally, extra-curricular activities consist of activities outside of those related to a course (Caza \& Brower, 2015). In the classroom, management education programs develop students' professional identities by socializing students about the expectations of managers (Costello, 2004; Ehrensal, 2016; Glaser-Segura, Mudge, 
Bratianu, \& Dumitru, 2010; Kelan, 2013) transmitting the behaviors, traits, and beliefs expected of a professional through case analysis, guest lectures, field trips, simulations, role plays, placements, internships, and presentations (Ehrensal, 2016). In recognition of the role of management education in the socialization of managers, the AACSB has explicitly included the ability to work in diverse work environments as a criterion in its business school accreditation program.

One form of informal curriculum is the hidden curriculum (Margolis, Soldatenko, Acker, \& Gair, 2001; Ottewill, McKenzie, \& Jean, 2005; Valieance, 1983). This hidden curriculum contains implicit assumptions and stereotypes about men's and women's management abilities (Margolis et al., 2001), reproducing cultural and social aspects of society, through teaching of behaviors (Giroux, 2001; Jackson, as cited in Margolis et al., 2001), ideology (Bowles \& Gintis as cited in Margolis et al., 2001), and values (Apple as cited in Margolis et al., 2001). It regularizes ways of knowing and speaking and various worldviews (Bourdieu, 1973). Because these underlying assumptions seem natural, they take on a sense of objectivity, rationality (Swiercz \& Ross, 2003), and neutrality resulting in an unquestioned truth (Klikauer, 2015) that precludes any debate. Thus, the hidden curriculum reinforces the belief that the education system is unbiased and neutral, while simultaneously reinforcing and perpetuating existing beliefs, values, ideologies, and behaviors (Bourdieu, 1973; Grenfell, 2008).

Cases, part of the pedagogical toolkit in management education programs for decades (Andersen \& Schiano, 2014; Garvin, 2007; Mesny, 2013), shape present and future practice by developing conventions, which become established as best practices that are passed onto new practitioners (Bridgman, Cummings, \& McLaughlin, 2016). Their use accounts for between $20 \%$ and $80 \%$ of instructional time in the top MBA programs worldwide (Levy, 2012). Furthermore, 
the case method appears to influence students' professional identities: it was the only pedagogy tested that predicted the development of a professional identity among undergraduate business students (Glaser-Segura et al., 2010). As a result, cases have the potential to inform, shape, and reinforce students' awareness, perceptions, and implicit knowledge of gendered organizational issues (Ehrensal, 2016).

Why does representation of women in cases matter? Protagonists in cases are distant role models whom students do not know personally but use as references for appropriate behavior; thus, cases are a powerful socialization tool. Relevant role models have been shown to be particularly important to women (Lockwood \& Kunda, 1997), demonstrating that it is possible to attain a managerial role (Chung, 2000). The lack of female protagonists in cases is significant because similarity between the student and the role model increases relevance of the role model for the student (Lockwood \& Kunda, 1997). For example, women choose a mix of male and female role models, while men tend to choose exclusively male role models (Singh, Vinnicombe, \& Kim, 2006). Furthermore, women see both male and female superiors as prospective role models (Javidan, Bemmels, Devine, \& Dastmalchian, 1995); in contrast, men do not see their female superiors as prospective role models (Javidan et al., 1995). Thus, management education programs' failure to provide students with female role models in business cases negatively affects both women and men. Women need to see female role models for aspirational purposes and men need to see successful female role models to normalize their perception of competent women managers.

A gendered analysis of case studies. In the context of management education, cases may contribute to the reinforcement of existing gendered norms. Positioned as rational (Swiercz \& Ross, 2003), evidence based, and quasi-experiential, case studies are assumed to be neutral 
with respect to gender, which is not perceived to be relevant to the decision at hand (Bridgman et al., 2016). Thus, most business cases tend to be rationalistic, strategy driven, and include an “under-socialized protagonist" (Liang \& Wang, 2004, p. 397).

Yet, the way that women are perceived is not neutral: studies show consistent differences, often negative, in the way that women are perceived when compared to traditional power holders in the West-white, heterosexual men (Grint, 2010). Only two traits associated with the ideal manager, both communal, are associated with women. All other traits associated with the ideal manager — including confidence, decisiveness, efficiency, and independence — are associated with men (Gmür, 2006). For example, women in comparison to men are perceived as less confident (Kay \& Shipman, 2014), less competent (Brescoll, 2011), more risk avoidant (Booth \& Nolen, 2012; Byrnes, Miller, \& Schafer, 1999), less creative (Proudfoot, Kay, \& Koval, 2015), less visionary (Ibarra \& Obodaru, 2009), less strategic and more tactical (Kaiser \& Wallace, 2016; Zenger \& Folkman, 2012), more emotional (Brescoll, 2016; Brescoll \& Uhlmann, 2008; Shields, MacArthur, \& McCormick, 2018), more ethical (Bart \& McQueen, 2013; Westphal \& Stern, 2007), more detail oriented (Ibarra \& Obodaru, 2009), less legitimate (Vial, Napier, \& Brescoll, 2016), and more communal and less agentic (Eagly \& Karau, 2002; Madera, Hebl, \& Martin, 2009).

Even the positively perceived female characteristics such as communality have different outcomes for men and women. For example, men are perceived as more promotable when they demonstrate communal leadership behaviors while women are not perceived to be more promotable when demonstrating the same behaviors (Hentschel, Braun, Peus, \& Frey, 2018). In addition, women's demonstration of ethical behavior makes them less likely to be on corporate boards (Westphal \& Stern, 2007). Finally, communal traits typically associated with women, 
including interpersonal communication and relationship management, are downplayed in the evaluation of team effectiveness (Metcalfe \& Linstead, 2003).

Absence of women in cases. Over 25 years ago, McKeen and Burke (1991) noted the importance of having female protagonists in business cases to prepare female students for managerial work. More than 20 years later, Symons and Ibarra (2014) examined the representation of women in 53 award-winning and best-selling case studies from The Case Centre published from 2000-2013, finding that women were absent in 23 cases (45\%) and were featured as protagonists in only five cases (9\%). In a follow-up study of 74 cases, Symons (2016) found that women were absent in 61 cases $(45 \%)$ and were protagonists in only six cases (8\%). Meanwhile, a content analysis of cases in one executive MBA program found that only $16 \%$ of the cases featured female leaders (Bennett \& Carroll, 2016). These findings raise troubling questions regarding the implicit and explicit messages conveyed to male and female business students. Schein's (1973) expression “think manager, think male” still seems to apply to business cases.

Depiction of women in cases. The characterizations of women in cases may be more stereotypical than we realize in the limited number of business cases in which they appear. An extreme example of these stereotypes appears in a fictionalized case assigned in recent years to first-year MBA students at the Rotman School of Business, University of Toronto. The case author portrays a female business student seemingly more focused on jewelry and designer shoes than on being a competent business executive. She is described as incapable of deciding which salary package to accept. She consults her boyfriend, who is portrayed as more competent. The case study notes that the student "really didn't want any of those investment banking or 
consulting jobs," and was "already dreaming of more little turquoise boxes on her bookshelf, where she already had quite a nice collection" (Mojtehedzadeh, 2014, para. 4).

Similarly, Tietz (2007) found that women's representation in accounting textbooks published from 2003 to 2005 tended to reinforce gender stereotypes, with men attributed with characteristics of successful managers such as confidence, careful thinking, effective teamwork, emotional neutrality, and the appearance of wealth. Women were less present than men, were more likely to be pictured in the domestic sphere, were described in less detail and, when included, tended to be situated in traditionally female "pink industries" such as fashion, food, family, and furniture, and situated in smaller firms (Tietz, 2007). Of the actual people (i.e., not fictionalized) portrayed in textbooks, only $11.6 \%$ were women (Tietz, 2007).

Symons and Ibarra (2014) found that women were more likely than men to be portrayed in pink industries, thus reinforcing the prejudice that women don't belong in the banking, finance, manufacturing or technology industries. Women were also more likely to be found in traditionally "pink organizations," such as non-profits, or traditionally female departments, for example, human resources. As a result, young women may feel that they belong only in the pink industries, organizations, or disciplines, but not in other sectors, thereby reinforcing patterns of sex segregation by industry and function (Symons, 2016). Finally, women were described in less length and detail than were men (Symons \& Ibarra, 2014).

We identified several limitations of the Symons and Ibarra (2014) study. In the study's sample, only five cases featured female protagonists. This small number of cases featuring female protagonists was not large enough to achieve theoretical saturation (Patton, 2014). Furthermore, almost $50 \%$ of the cases in the sample featured multinational corporations and they were disproportionately based on secondary sources, which, because the case authors do not 
have access to the actors, but rather rely on published accounts of the situation, tend to provide less-rich descriptions of the protagonist; thus, they were not representative of the broader spectrum of cases featuring female protagonists. Additionally, Symons and Ibarra conducted a descriptive analysis, coding only hard, concrete, observable data (Morse, 2018), such as whether a woman is mentioned, whether she is the protagonist, whether she speaks to another woman, the industry setting of the case, and the length of the description of the woman (Symons \& Ibarra, 2014). Because they did not use an interpretive approach, their analysis lacked a more nuanced understanding of the portrayal of women's traits, behaviors, skills, and character in cases (Morse, 2018). Finally, their study did not compare the representation of female protagonists to that of male protagonists.

Given the concern about the lack of women in cases and the limited research about the portrayal of women in cases, we decided to explore cases using a language-based analytic approach. Our objective was to validate and extend Symons and Ibarra's (2014) study. In addition to replicating their descriptive analysis, we sought to gain a deeper understanding of the way in which case authors might be reinforcing the gendered norms of management, through an interpretive analysis of representations of women's and men's visions, leadership abilities, professional identities, behaviors, and traits.

\section{Method}

Prompted by Dean Nohria's apology to female alumnae and by Symons and Ibarra's (2014) analysis of women's presence in cases, we began our study in the fall of 2014, drawing our sample of cases from the Ivey Publishing collection published between August 14, 2013 and August 14, 2014. 


\section{Sample}

We selected only cases published by Ivey, rather than cases from other publishers distributed by Ivey Publishing. We chose Ivey cases for several reasons: Ivey is the secondlargest case publisher worldwide, accepts submissions from academics worldwide, and its cases are peer reviewed. By focusing on one publishing outlet, we avoided inconsistencies in criteria for publication, presentation, classification, and editorial standards across publishing outlets. Additionally, Ivey Publishing provides easy access to teaching notes (many case publishers do not), which we used to determine the objectives of each case and identify any disguises.

We drew 296 cases that had teaching notes and were written in English. We then excluded 30 cases categorized as general experience (material based on the author's acquired experience), supplementary materials, exercises, descriptive cases, those that had a fictionalized female character, or where the actual protagonist was a male but disguised as a female. Of the remaining 266 cases in the pool, 51 featured female protagonists. Then, using the discipline, industry, and geography of each case featuring a female protagonist, we identified 51 matching cases featuring male protagonists published by Ivey during the same period. See Appendix A for a list of cases with female protagonists and Appendix B for a list of cases with male protagonists.

We chose to include the entire corpus of cases featuring women protagonists (rather than a small sample) and a matching sample of cases featuring male protagonists in the Ivey Publishing database to increase the likelihood that we would attain theoretical saturation (Patton, 2014), which provided us with enough data to identify themes, to build connections, and to explore patterns of representations of women and men in cases. 


\section{Code Development}

We conducted a content analysis of the representations of both the men and women in our sample (Cohen, Manion, \& Morrison, 2011). We began our coding process by creating a start list (Miles, Huberman, \& Saldana, 2013) of 15 possible interpretive codes, based on previous content-analysis studies of textbooks (Gabriel, 1990; Tietz, 2007) and previous research, showing that women are stereotyped as collaborative (Manuel, Shefte, \& Swiss, 1999), emotional (Shields et al., 2018), and risk averse (Byrnes et al., 1999). Further, women are shown to be communal and democratic while men are shown to be agentic, confident, independent, and autocratic (Eagly \& Karau, 2002). We adopted Symons and Ibarra’s (2014) descriptive codes, for example, industry, length of descriptions, and length of quotations.

We randomly selected and coded six Ivey cases featuring female protagonists published between August 2012 and August 2013 to more fully develop our initial codebook, to calibrate our code definitions, and to familiarize ourselves with the NVivo 11 software. We both coded all six cases, incorporating new codes as they emerged using both inductive and deductive approaches (Cohen et al., 2011). Then, we compared our coding of each case to ensure intercoder consistency. As a result, we more tightly defined each code, eliminated infrequently used codes, and identified possible codes that emerged inductively (Miles et al., 2013). For classifications such as business discipline, firm size, geography, industry type, author, and case source, we used the classifications on Ivey Publishing's website (See Appendix C for the codebook). We then coded all 102 cases in the sample, using a step-wise process (Anney, 2014) to ensure confirmability of our analysis (Lincoln \& Guba, 1985). We conducted multiple passes through the cases (Cohen et al., 2011), identifying emergent codes and refining existing codes. 


\section{Analysis}

\section{Descriptive Data}

Of the 266 cases in the sample pool, 51 (19\%) featured female protagonists. Our sample included an additional 51 cases featuring male protagonists, for a total sample of 102 cases. As noted in Table 1, the sample consisted primarily of field cases (86\%) set in small- and mediumsize enterprises (53\%), although the male cases did skew slightly to large organizations (44\% of the male cases as compared to $33 \%$ of the female cases). The cases were set primarily in Canada/U.S. (50\%) or the Asia Pacific region (30\%). In terms of discipline, the cases were in general management/strategy (37\%), marketing (22\%), entrepreneurship (14\%), and organizational behavior/human resources (12\%).

\section{Insert Table 1}

Since the sample of male cases was drawn to control for discipline, geographic setting, and case source (field or secondary source case), the sample of male cases is not representative of all cases featuring male cases in the Ivey database. As a result, to analyze representation of women in cases in "pink" industries, we looked at all male cases published in the 2013 to 2014 sample window and compared them to all female cases. We also considered the employment rates of women and men in these industries (Government of Canada, 2015). Our findings in Table 2 show that while women were overrepresented in cases in several categories, once we controlled for employment, we did not find any overrepresentation of women's cases in pink industries, unlike Symons and Ibarra's (2014) findings.

Insert Table 2 


\section{Absence and Presence of Women and Men in Cases}

Only $19 \%$ of the cases in the sampling frame featured female protagonists, yet this proportion was double the rate found in Symons and Ibarra's (2014) study of best-selling cases.

Our search of the Ivey Publishing database suggests that women are even more underrepresented in best-selling cases: of the 96 best sellers that were in the Ivey collection, in English with teaching notes, excluding general experience cases, only six cases $(6 \%)$ featured a female protagonist. This small proportion may reflect the relative underrepresentation of women in cases situated in large firms, as best sellers tend to be set in large, well-known multinational firms (M. Quinn, Director, Ivey Publishing, Personal Communication, June 5, 2014).

We conducted a deeper analysis into the gender of the characters featured in the case sample, finding that in $37 \%$ of the female cases, women protagonists were the sole focus of the case, while in $65 \%$ of the male cases, the male protagonist was the sole focus of the case. Other characters of the opposite gender (co-protagonists and secondary characters) were represented in $45 \%$ of the female cases and $29 \%$ of the male cases. Thus, the focus on female protagonists appears to be more diffuse than the focus on male protagonists in business cases.

\section{Insert Table 3}

Furthermore, the description of other characters in the female cases tends to be more frequent and extensive than in the male cases ${ }^{1}$, as shown in Table 4 . In female cases, there were 2.8 times as many references to other female characters and 2.0 times as many references to other male characters than in cases featuring male protagonists. In addition to tracking the number of cases and frequency of references, we also tracked case coverage. We defined case coverage as the

\footnotetext{
${ }^{1}$ We noted in our analysis that while cases differed in terms of frequency and case coverage of the portrayals of male and female protagonists, often the language used to describe the case characters did not vary significantly between male and female protagonists. See the online-only supplementary materials to this article for exemplar quotes.
} 
number of words coded to a variable as a percentage of the number of words in the case text. A higher case coverage indicates a greater proportion of the case is devoted to that variable and thus suggests that the author put a greater emphasis on that variable. Case coverage of the descriptions of the other characters in female cases was 1.8 times greater than that found in male cases, further reinforcing the diffusion of focus to other characters in female cases.

\section{Insert Table 4}

This trend continued when we examined direct quotations in the cases. In Table 5, we see that female protagonists were quoted in fewer cases, less frequently, and less extensively than were male protagonists. While male protagonists' quotations covered $2.6 \%$ of the case length, female protagonists' quotations covered only $1.4 \%$ of the case length. Moreover, in the female cases, other characters (co-protagonists, other women, and other men) were quoted in more cases, more frequently, and more extensively, than were the female protagonists. The reverse pattern occurred in cases featuring male protagonists - other characters were quoted in fewer cases, less frequently, and less extensively than were the male protagonists.

\section{Insert Table 5}

We noticed another interesting pattern with respect to a protagonist's team in cases. Authors used the term "and her [or his] team" more frequently for female protagonists than male protagonists to signify the context of working with their team. In addition, these descriptions of the female protagonists and their teams covered a greater proportion of the case text, as noted below in Table 6.

\section{Insert Table 6}

These descriptions of working with her team tended to refer to an action or a decision taken, diluting the role of the female protagonist in that action or decision. References to "and her 
team" could signal the female protagonist's legitimacy as a team leader or that she shares power and encourages participation of others. However, we believe that, combined with our findings regarding the presence and coverage of other characters in female cases, these references tend to reinforce the diffusion of the female protagonists' power, authority, and accountability. In summary, the descriptive data show that female protagonists were underrepresented in cases, and in cases featuring female as compared to male protagonists, other characters were more frequently represented and their quotes covered more of the case, suggesting that female protagonists' presence and voice are less dominant than we see in cases featuring male protagonists.

\section{Interpretive Data}

Cases provide distant role models that demonstrate appropriate managerial traits, behaviors, and beliefs to students; these elements in turn inform the development of their professional identities (Glaser-Segura et al., 2010). Thus, the portrayal of women and men in business cases shapes students' understandings of the characteristics and behaviors associated with management professionals. Two broad themes emerged in our analysis: first, women's leadership is represented differently than men's; and, second, women's personal attributes, characteristics, and behaviors are represented in a stereotypical manner.

\section{Theme 1: Women's Leadership is Represented Differently}

Researchers and practitioners have cited vision as a crucial element of organizational leadership (Bass \& Avolio, 2018; House \& Shamir, 1993; Kouzes \& Posner, 2012; Margolis \& Ziegert, 2016; van Knippenberg \& Stam, 2014). According to Ibarra and Obodaru (2009), envisioning is a particularly important aspect of leadership: leaders must sense changes in the environment, identify opportunities, engage others in the development of the vision, 
communicate the vision, and motivate or inspire others to attain the vision. Women executives tend to be rated lower than their male colleagues on envisioning (Ibarra \& Obodaru, 2009). As a result of these previous studies, we expected that less text about vision and visioning would be found in the women's cases. We also expected that the male cases would anthropomorphize the organization by attributing vision to the organization rather than to a person, for example, “3M's vision for the future" not "John's vision for the future," as the cases in the male sample were skewed to large organizations, while the cases in the female sample were skewed to small- and medium-sized organizations. We consider attribution of vision in our analysis in Table 7.

\section{Insert Table 7}

In cases featuring female protagonists, we found a higher frequency of vision statements attributed to the protagonist, but these statements were much shorter than those in cases featuring male protagonists. While there were 55 references to vision, mission, or strategic objectives in female cases and only 44 in male cases, the references in female cases were less detailed, encompassing just over half of the case coverage of the references in male cases.

We observed a different pattern when the references to vision were attributed to the organization. While the number of references of vision attributed to organization continued to be lower for female cases than male cases, these references were substantially longer -2.3 times the proportion of the case dedicated to of attributions of vison in male cases. This pattern of attribution of vision to organizations, instead of individuals is consistent with the earlier pattern of diffusion we noted earlier regarding the female protagonists' impact on action and decision to other people.

We decided to conduct a deeper analysis of some of the constituent elements of vision passion, creativity, and sensing. As seen in Table 8, women protagonists were described as 
having dreams or passion less frequently and with less emphasis than were male protagonists. Women's creativity was described less extensively than was men's, consistent with what the literature suggests (Costa, Terracciano, \& McCrae, 2001). With respect to intuition and sensing, women protagonists were described as sensing less frequently—but covering a greater proportion of the case — than descriptions of male protagonists.

\section{Insert Table 8}

Thus, our findings accord with those of Ibarra and Obodaru (2009): women are represented as less visionary and creative. At the same time, it appears that some of women's vision is attributed to the organization, rather than to the women themselves, despite their greater representation in small and mid-sized organizations where one might expect vision to be voiced by senior personnel.

Power. In an analysis of power in organizations, female protagonists are underdescribed with respect to all forms of power. Legitimate power is derived from a position or organization (Daft \& Lane, 2014), referent power is the power that sources from likability, expert power is based on hard-to-replace knowledge, coercive power arises from the capacity to use punishment (Johns \& Saks, 2014), and reputational power arises from the collective evaluations of an individual's power by others in the field (Fischer \& Sciarini, 2015). Rather astonishingly, female protagonists in the female cases were explicitly identified as holding legitimate power in only two cases, while men's legitimate power was identified in 48 of 51 male cases. In terms of expert power, female protagonists are represented in only 5 of the 51 female cases; this low number starkly contrasts with the 43 of 51 male cases in which the expert power of the male protagonists is noted. Similarly, women are underrepresented in reputational power. As noted in Table 9, references to empowering others occurred in a 3:1 ratio of female relative to male protagonists. 
Insert Table 9 Risk-Taking and Risk Averse. Female protagonists were four times more likely to be described as risk averse. In contrast, authors described a male protagonist as risk averse in only one case. A greater number of female cases also discussed risk-taking as a strategy for managing the situation at hand.

Rational, Decisive, Evidence Based. Female cases, in relation to male cases, showed a lower number of references to being rational and decisive and, most notably, a lower mean percentage of case coverage, as shown in Table 10.

\section{Insert Table 10}

Collaboration. Collaboration was noted at three levels - interpersonal, intraorganizational, and interorganizational. Although male and female protagonists had equally frequent references to interpersonal collaboration, female protagonists were noted as engaged in fewer intraorganizational and interorganizational collaborations than male protagonists. For interorganizational collaborations, relative to the male cases, female cases only noted interorganizational collaborations in $31 \%$ of cases (See Table 11).

\section{Insert Table 11}

Agentic Behaviors. Leaders, by definition, are involved in agentic behaviors. They inspire action and focus on change. Agentic behavior was more frequently associated with male protagonists than female protagonists. The ratio of female to male agentic references was 0.29:1 (See Table 12).

\section{Insert Table 12}

Leadership crucibles are generally defined as difficult, challenging, or traumatic experiences in which individuals find new meanings that lead to a new or altered personal identity (Bennis \& Thomas, 2002). Overall, references in women's cases to a leadership crucible 
appeared in fewer cases and were less frequent than those in male cases, although they covered the same proportion of the case text. In fact, in cases where a leadership crucible is mentioned, women's cases on average contained 1.3 references to a leadership crucible, while male cases contained 2.5 references. Since female and male cases had roughly equal case coverage and women have far fewer references to leadership crucibles, it would appear that when a leadership crucible is introduced in a women's case, it covers much more of the case, suggesting that the authors placed a significant emphasis on the crucible experience.

Insert Table 13

\section{Theme 2: Women are Portrayed Stereotypically}

Women tend to be perceived as more emotional (Shields et al., 2018), more cautious (Bird \& Brush, 2002), more ethical (McCabe, Ingram, \& Dato-on, 2006), and less certain than men (Kay \& Shipman, 2014). In general, we found a similar pattern of representations in our sample.

Emotion. Baxter (2010) suggests that through discourse, gendered differences are reproduced and reinforced such that "males are viewed as more rational, independent and competitive and confrontational" (pp. 43-44), while women are seen as emotional (p. 44). As Table 14 illustrates, female protagonists were referred to as emotional three times more often than male protagonists. In addition, authors placed much greater emphasis on female protagonists' feeling overwhelmed than they did on the male protagonists-by a ratio of $3: 1$. In a related issue, women were represented as needing emotional support, with twice as many references to this need by female protagonists than by male protagonists.

Cautious. Female protagonists were described as cautious 2.5 times more frequently than were men and 2.7 times greater coverage in the female cases and this pattern occurred in roughly $25 \%$ of all female case as compared to $12 \%$ of male cases. 
Certainty vs. Uncertainty. Shipman and Kay (2014) suggest that women demonstrate less confidence in their abilities. In the characterization of male and female protagonists, female protagonists were much less frequently identified as being certain than male protagonists. In female cases, the mean number of references to certainty was less than half that of men in male cases. The number of references to certainty in male cases was almost three times that noted in the female cases.

Values/beliefs. More male than female cases involved a corporate social responsibility or ethics component, yet female cases featured a more extensive descriptions of the values and corporate social responsibility drivers for female protagonists than for male protagonists — case coverage was over 7.6 times that of the male cases.

\section{Insert Table 14}

Quality and Detail Oriented. The focus on a quality orientation of the protagonist was noted in $40 \%$ more female cases than male cases and by a similar margin in terms of case coverage of female cases versus male cases. Women's identity and focus was more tied to product quality than was evident among the male protagonists. Furthermore, descriptors of the protagonist as detail oriented appeared in nearly twice as many female cases as male cases. Taken together, these factors reinforce the perception that women focus on details at the expense of bigger picture strategy and vision (Ibarra \& Obodaru, 2009).

Assertive. Somewhat surprisingly, female protagonists were described as assertive, or being determined, driven, or intense. This description occurred in 50\% more female cases than male cases, and case coverage was 3.5 times greater in female cases than male cases. The notable presence of this factor in the female cases highlights the counter-stereotypical behavior to that associated with women (Eagly \& Karau, 2002). 
Credibility and Lacking Credibility. One of the more striking differences relates to the credibility of the protagonists. As noted in Table 14, authors devoted 3.5 times the case coverage to establishing the credibility of female protagonists as compared to male protagonists. Furthermore, while none of the male cases discussed, mentioned, or alluded to a male protagonist as lacking credibility, 12 of the 51 female cases provided notes concerns regarding a female protagonist's credibility. For instance, "Chaudhury did not realize that the soft tonality of her email—given her past stance on injustice against women — was an action that Tehelka employees, media, online forums and the public at large would question repeatedly in times to come" (Agarwal, 2013, p. 3).

Issues with no real difference between male and female protagonists. Female and male protagonists are not portrayed differently in the following areas: inclusion of information regarding credentials, optimism, or being concerned or anxious. In addition, there were qualities that were evident in such a low number of cases (e.g., only one case) that they were excluded from analysis (e.g., being brave, as well as demonstrating coercive power). Furthermore, only one case in our sample discussed issues of sexual harassment, and, ironically, the female protagonist in the case was accused of supporting a male harasser against a female employee (Agarwal, 2013). We found no cases that articulated issues of gender bias and resulting discrimination. The only case dealing with work-life balance featured a male protagonist in the Deloitte Consulting GTA: The Deloitte Dads Initiative (Konrad \& Shuh, 2013).

\section{Discussion}

We often hear instructors making comments like, "I teach finance (or marketing or IT) and talking about bias against women isn't relevant to finance." We offer a different perspective on the question of relevance. We believe that an instructor's role is not only to teach finance, but 
to teach students to become effective financiers who are able to lead others. Thus, teaching a subject is more than learning the technical skills required in a discipline. Teaching includes embracing the complex social context in which students will "do" the subject. Building students" awareness and questioning of the implicit, dominant assumptions that underpin management (Bridgman, McLaughlin, \& Cummings, 2018) will prepare them to better influence, persuade, collaborate with and manage others during their careers. Learning about the biases against women in recruiting, performance evaluation, and promotion will help both male and female students more fairly evaluate women's performance and will help women develop the skills that they need to succeed in their chosen discipline.

Promoters of the case method value its perceived objectivity, which fosters a rational, analytical approach to decision-making (Bridgman et al., 2016). Conversations of values, ethics, or moral positions that might result from a decision are not often entertained in case discussions (Anteby, 2013). Cases, however, deliver a common business ideology "presented as unquestioned truths, as neutral and natural" (Klikauer, 2015, p. 1106). They subtly influence the socialization of the next generation of managers and leaders and the development of their managerial identities by demonstrating expected behaviors, beliefs, and values of managers and leaders. Taking a "gender neutral" approach merely reaffirms the status quo, reinforcing unconscious assumptions that effective managers adopt male traits and behaviors (Bergvall \& Remlinger, 1996).

As Ibarra (1999) concluded, young professionals develop their professional identities by observing the behaviors of aspirational role models, trying those behaviors themselves, and determining whether the identity in question fits them. Cases allow students to observe the behaviors of various managers and metaphorically walk in their shoes (Bridgman et al., 2016). 
How authors portray various characters indicates appropriate roles, behaviors, and identities for managers and leaders. Thus, cases play a key part in the hidden curriculum of management education programs, reinforcing the status quo, including the "think manager, think male" (Schein, 1973) stereotype.

\section{Implications}

Our research has several implications for teaching practice that can be categorized into four distinct phases: ongoing reflective practice, pre-course planning, pre-class planning, and the unplanned "teachable moment."

Preparing to teach controversial, highly emotional topics can be intimidating, especially if instructors feel that they do not have the credibility or knowledge to address these issues among students. Argyris (1994) notes that people often try to avoid shame and embarrassment by not acknowledging or acting on information that could threaten their self-image. By adopting a more reflective teaching practice (Baker, 2004; Ritchhart, Church, \& Morrison, 2011), instructors can explore the differences between their expressed theories of management and their theories in action (Argyris, 1980, 1994), thereby becoming more aware of both their own biases and those in their pedagogy (Baker, 2004). For example, we suggest that instructors take the Harvard Implicit Association (IAT) gender-career test (“Gender-Career IAT," n.d.) to understand whether they hold any implicit bias against men or women in the workplace and/or explore the concept of implicit bias by reading books such as Blind Spot: Hidden Biases of Good People (Banaji \& Greenwald, 2013). We also recommend that instructors explore and share personal experiences with respect to stereotypes in the classroom. By role modelling vulnerability and trust in the classroom, instructors can build a psychologically safe space for students to explore issues of bias (Baker, 2004). 
During the pre-course planning phase, we encourage instructors to include cases featuring female protagonists and to look for a balance of representations of women's traits and actions, for example, including both stereotypically communal and counter-stereotypically agentive behaviors. Since best-selling cases tend to underrepresent women protagonists to a greater extent than the overall catalogue, we suggest that instructors search beyond the best-sellers list. Some case publishers have search filters for female protagonists that can help instructors quickly find available cases. We recognize that cases featuring women are in short supply in some disciplines (e.g., technology and finance), but it is in these male-dominated disciplines that negative stereotypes about women's management abilities remain the strongest (Eagly \& Karau, 2002), so we suggest offsetting this shortage by inviting female professors, executives, and mentors into your classroom. We have found that reaching out to other faculty members can often yield long lists of women executives interested in participating in classroom activities. Alumnae, in particular, offer students an opportunity to engage with successful female role models. Alternatives to written cases could include news articles or videos featuring female decision makers. We suggest avoiding selecting or writing fictionalized cases that feature female protagonists, as our experience suggests that they may be perceived by students as less credible or as an irrelevant politically correct move on the part of the instructor. Instructors can also present evidence-based research on the relationship between gender, management behavior, and effectiveness (e.g., Powell, 2011).

The pre-class planning phase involves developing a psychologically-safe environment for students to engage in constructive conflict (Baker, 2004). We suspect that faculty often avoid these types of discussions because they have the potential to become heated and spin out of control. Co-constructing class civility rules may provide guidelines for instructors and students 
to discuss these challenging issues (Baker, 2004; Marini, Polihronis, \& Blackwell, 2010). The Devil's Advocate strategy (Pearce, 2002) can be an effective way of creating constructive conflict when discussing a case. It requires that students develop an assigned position on an issue, in which they analyze the situation and underlying assumptions of the opposing perspective. Perspective-taking thinking routines, including Circle of Viewpoints, Step Inside, and Tug of War (Ritchhart et al., 2011) can provide instructors a structured way to help students safely explore various points of view on gender in an organizational context.

Anticipating emotional conversations and preparing in advance to debrief these emotions may also be helpful. For example, using the four "Es" model of emotional debriefing (events, emotions, empathy, and explanation) (Petranek, Corey, \& Black, 1992) may help instructors feel more confident in tackling emotionally-charged issues in the classroom. Practicing empathy may be the most effective way to help students deal with any shame or embarrassment (Brown, 2006) they might experience as they learn about implicit bias. In particular, helping students understand that implicit bias is a universal cognitive trait (Banaji, Bhaskar, \& Brownstein, 2015) can mitigate their embarrassment and shame. For example, the career-gender test shows that $75 \%$ of men and $80 \%$ of women automatically associate male with career and female with family (Banaji \& Greenwald, 2013).

Finally, there is the "teachable moment," the unexpected comment made during a class discussion which opens the opportunity to address an "undiscussable" topic (Argyris, 1980), those topics that are threatening and risky, such as gender in organizations, which may lead students to question their underlying assumptions and values. First, the instructor needs to be alert to allusions to the "undiscussable" and comfortable with taking the time to open a conversation about the moment in the classroom (Baker, 2004). By noticing and naming implicit 
biases (Ritchhart et al., 2011) during case discussions, instructors can role model a thinking routine that will help students develop their own awareness of bias. The instructor can name what they just saw or heard and comment on their own experience of it, in a neutral manner, such as "that made me uncomfortable" (Baker, 2004, p. 700). Alternatively, the instructor could repeat the student's statement and ask “what makes you say that?” (Ritchhart et al., 2011, p. 165). This strategy allows the instructor to expose the hidden assumptions behind a specific statement, exploring a claim and its support in a critical thinking exercise.

\section{Limitations}

There are some limitations to this study. Cases are filtered and framed by their authors to ensure that students attain certain learning outcomes. It is difficult to ascertain whether authors consciously or unconsciously shape the representation of the protagonist through selection of specific quotations and descriptors. Furthermore, disguises are routinely used in cases and are not always noted in teaching notes or other materials. Cases written based on secondary sources may have an additional filter further distorting or exaggerating the representation of the various characters in a case. Finally, our sample is drawn from a single source of published cases. Although the sample includes cases written by business school faculty from all over the world, there may be biases based on this limited sampling frame.

\section{Areas for Future Research}

Our study raises further questions regarding the presence, absence, and representation of women in the workplace. Teaching notes, which typically accompany a business case, also offer potential insights. The teaching note provides an instructional road map that may include implicit messages about gender and diversity in the workplace. In addition, the suggested discussion questions included in a teaching note would give an indication of whether gender issues are part 
of the discussion points identified by the case authors. Adopting a systematic and detailed discourse analysis of the text of cases could potentially develop a more finely-grained understanding of the representation of female protagonists both by the case author or authors, as well as self-representation of female protagonists within verbatim quotations attributed to the protagonist. Finally, research about the relative invisibility of other non-dominant groups (for example, people of color, of different religions, sexual identities, sexual orientations, or with disabilities) in cases might help management educators challenge students' implicit assumptions about the traits of effective managers.

\section{Conclusions}

This study replicates the work of Symons and Ibarra (2014) analyzing the descriptions of women and their organizations in a larger sample of cases featuring women protagonists and extends their work by including an interpretive analysis of the behaviors, beliefs, and traits attributed to female protagonists and by analyzing the portrayals of male protagonists. Our analysis suggests women protagonists are invisible in over $80 \%$ of cases and represented in a clichéd manner in the remaining cases, reinforcing existing beliefs, values, ideologies, and gendered behaviors in the business world. Women's absence as decision makers in cases is a glaring example of this reinforcement. Where women are featured, their descriptions tend to comprise a lower share of the case, they are quoted less frequently, and at less length. The female protagonists' presence appeared to be diluted by the presence of other characters in the case, which did not occur in the cases featuring male protagonists. Cases also portray women in as less visionary, creative, powerful, risk-taking, and agentic than male protagonists. Authors used crucible events to explain sex-role stereotyped choices. Furthermore, women were more likely to be characterized stereotypically, portrayed as more emotional, cautious, and quality and detail 
oriented and less certain than men. Authors allocated more space to establishing women's credibility but were also more likely to highlight women's lack of credibility.

These cases simultaneously undervalue the positive skills that women bring to business by diluting their contributions and devaluing attributes such as emotion or collaboration, while implying that women do not have the skills and behaviors, such as agency, risk-taking, or visionmaking necessary to be successful managers and leaders (Carter \& Silva, 2007). This devaluation may, in part, explain why women's association of women's attributes with the role of manager declines over a four-year business undergraduate degree (Paris \& Decker, 2012). At the same time, women may be deterred from developing non-stereotypical, agentive behavior, and non-traditional skills that will help them progress in the workplace. This may contribute to the almost immediate reduction of women in the managerial pipeline. A second implication of the absence and portrayal of women in cases is that young men will continue to perceive women in stereotypical ways, reducing the likelihood that future male managers will make promotion decisions that equalize the number of male and female managers. Finally, people have been shown to behave consistently with gender stereotypes (Greenwald \& Banaji, 1995), which are unconscious, implicit, easily triggered, and resistant to change (Banaji et al., 2015; Banaji \& Hardin, 1996). Therefore, it is imperative that we as educators work to identify and reduce stereotypical representations of women to students.

As educators, we consciously and unconsciously shape our students' identities as managers and leaders through what we teach, how we teach it, our choices as role models, the discussions we entertain in the classroom, and the materials we select. We prepare students for the workplace by recognizing both who is represented in cases and who is not, as a stepping stone to providing 
students with a broader, more inclusive understanding of the people who compromise contemporary organizations. 


\section{References}

AACSB. (2016). AACSB business school data guide 2016 (pp. 1-56). Tampa, FL. Retrieved from http://www.aacsb.edu/-/media/aacsb/publications/data-trendsbooklet/2016.ashx?la=en

Agarwal, S. (2013). Tehelika in crisis (Ivey ID 9B14M081). London, ON: Ivey Publishing. Retrieved from https://www.iveycases.com/ProductView.aspx $? \mathrm{id}=65218$

Andersen, E., \& Schiano, B. (2014). Teaching with cases: A practical guide. Boston, MA: Harvard Business Review Press.

Anney, V. N. (2014). Ensuring the quality of the findings of qualitative research: Looking at trustworthiness criteria. Journal of Emerging Trends in Educational Research and Policy Studies, 5(2), 272-281.

Anteby, M. (2013). Manufacturing morals: The values of silence in business school education. Chicago, IL; London, UK: University of Chicago Press.

Apple, M., \& King, N. (1983). What do schools teach? In H. A. Giroux \& D. E. Purpel (Eds.), The hidden curriculum and moral education: Deception or discovery? (pp. 81-99). Berkeley, CA: McCutchan Publishing Corp.

Argyris, C. (1980). Making the undiscussable and its undiscussability discussable. Public Administration Review, 40(3), 205-213. https://doi.org/10.2307/975372

Argyris, C. (1994). Good communication that blocks learning. Harvard Business Review, 72(4), $77-85$.

Baker, A. C. (2004). Seizing the moment: Talking about the "undiscussables." Journal of Management Education, 28(6), 693-706. https://doi.org/10.1177/1052562903252661 
Banaji, M. R., Bhaskar, R., \& Brownstein, M. (2015). When bias is implicit, how might we think about repairing harm? Current Opinion in Psychology, 6, 183-188.

Banaji, M. R., \& Greenwald, A. G. (2013). Blindspot: Hidden biases of good people (1st ed.). New York, NY: Delacorte Press.

Banaji, M. R., \& Hardin, C. D. (1996). Automatic stereotyping. Psychological Science, 7(3), 136-141.

Bart, C., \& McQueen, G. (2013). Why women make better directors. International Journal of Business Governance and Ethics, 8(1), 93-99.

Bass, B. M., \& Avolio, B. J. (2018). Improving organizational effectiveness through transformational leadership. Thousand Oaks, CA: SAGE Publications. Retrieved from https://us.sagepub.com/en-us/nam/improving-organizational-effectiveness-throughtransformational-leadership/book4228

Baxter, J. (2010). The language of female leadership. Basingstoke, UK: Palgrave Macmillan.

Bennett, J., \& Carroll, W. R. (2016). Replicating Symons'study of women's representations in business school cases: A content analysis of an EMBA program case studies. Presented at the Atlantic Schools of Business, Halifax, NS.

Bennis, W., \& Thomas, R. J. (2002, September 1). Crucibles of leadership. Retrieved from https://hbr.org/2002/09/crucibles-of-leadership

Bergvall, V. L., \& Remlinger, K. A. (1996). Reproduction, resistance and gender in educational discourse: The role of critical discourse analysis. Discourse \& Society, 7(4), 453-479. https://doi.org/10.1177/0957926596007004002

Bird, B., \& Brush, C. (2002). A gendered perspective on organizational creation. Entrepreneurship: Theory \& Practice, 26(3), 41-65. 
Booth, A. L., \& Nolen, P. (2012). Gender differences in risk behaviour: Does nurture matter? Economic Journal, 122(558), F56-F78. https://doi.org/10.1111/j.14680297.2011.02480.x

Bourdieu, P. (1973). Outline of a theory of practice. (R. Nice, Trans.). Cambridge, UK: Cambridge University Press.

Brescoll, V. L. (2011). Who takes the floor and why: Gender, power, and volubility in organizations. Administrative Science Quarterly, 56(4), 622-641. https://doi.org/10.1177/0001839212439994

Brescoll, V. L. (2016). Leading with their hearts? How gender stereotypes of emotion lead to biased evaluations of female leaders. The Leadership Quarterly, 27(3), 415-428. https://doi.org/10.1016/j.leaqua.2016.02.005

Brescoll, V. L., \& Uhlmann, E. L. (2008). Can an angry woman get ahead? Status conferral, gender, and expression of emotion in the workplace. Psychological Science, 19(3), 268275. https://doi.org/10.1111/j.1467-9280.2008.02079.x

Bridgman, T., Cummings, S., \& McLaughlin, C. (2016). Restating the case: How revisiting the development of the case method can help us think differently about the future of the business school. Academy of Management Learning \& Education, 15(4), 724-741. https://doi.org/10.5465/amle.2015.0291

Bridgman, T., McLaughlin, C., \& Cummings, S. (2018). Overcoming the problem with solving business problems: Using theory differently to rejuvenate the case method for turbulent times. Journal of Management Education, 42(4), 441-460. https://doi.org/10.1177/1052562917754236 
Brown, B. (2006). Shame resilience theory: A grounded theory study on women and shame. Families in Society: The Journal of Contemporary Social Services, 87(1), 43-52. https://doi.org/10.1606/1044-3894.3483

Brown, J. (2016, March 22). Women as full-time business school faculty - does world region make a difference? Retrieved April 18, 2018, from http://aacsbblogs.typepad.com/dataandresearch/2016/03/women-as-full-time-businessschool-faculty-does-world-region-make-a-difference.html

Brown, J. (2017, February 24). The percentage of women as full-time faculty at U.S. business schools: Surging ahead, lagging behind, or stalling out? Retrieved April 18, 2018, from http://aacsbblogs.typepad.com/dataandresearch/2016/02/the-percentage-of-women-asfull-time-faculty-at-us-business-schools-surging-ahead-lagging-behind-or-.html

Byrne, J. A. (2014, January 28). HBS Dean makes an unusual public apology. Retrieved April 18, 2018, from https://poetsandquants.com/2014/01/28/hbs-dean-makes-an-unusualpublic-apology/

Byrnes, J. P., Miller, D. C., \& Schafer, W. D. (1999). Gender differences in risk taking: A metaanalysis. Psychological Bulletin, 125(3), 367-383. http://dx.doi.org.proxy1.lib.uwo.ca/10.1037/0033-2909.125.3.367

Carter, N. M., \& Silva, C. (2007). The double-bind dilemma for women in leadership: Damned if you do, doomed if you don't. Catalyst. Retrieved from http://www.catalyst.org/knowledge/double-bind

Caza, A., \& Brower, H. H. (2015). Mentioning the unmentioned: An interactive interview about the informal management curriculum. Academy of Management Learning \& Education, 14(1), 96-110. https://doi.org/10.5465/amle.2013.0164 
Chung, K.-S. (2000). Role models and arguments for affirmative action. The American Economic Review, 90(3), 640-648.

Cohen, L., Manion, L., \& Morrison, K. (2011). Research methods in education (7th ed.). London, UK; New York, NY: Routledge.

Costa, P. T., Terracciano, A., \& McCrae, R. R. (2001). Gender differences in personality traits across cultures: Robust and surprising findings. Journal of Personality and Social Psychology, 81(2), 322-331. http://dx.doi.org.proxy1.lib.uwo.ca/10.1037/00223514.81 .2 .322

Costello, C. Y. (2004). Changing clothes: Gender inequality and professional socialization. NWSA Journal, 16(2), 138-155.

Daft, R. L., \& Lane, P. G. (2014). The leadership experience (6th ed.). Mason, OH: Cengage Learning.

Drozdowski, H. (2013, March 8). Do female-led b-schools render higher female enrollment? Retrieved from http://aacsbblogs.typepad.com/dataandresearch/2013/03/do-female-led-bschools-render-higher-female-enrollment.html

Eagly, A. H., \& Karau, S. J. (2002). Role congruity theory of prejudice toward female leaders. Psychological Review, 109(3), 573-598. http://dx.doi.org.proxy1.lib.uwo.ca/10.1037/0033-295X.109.3.573

Ehrensal, K. N. (2016). Making managers: Towards an understanding of how textbooks, lectures and management case studies interact to inculcate linguistic and managerial habitus in undergraduate business students. Tamara Journal for Critical Organization Inquiry, $14(2), 65-73$. 
Fischer, M., \& Sciarini, P. (2015). Unpacking reputational power: Intended and unintended determinants of the assessment of actors' power. Social Networks, 42, 60-71. https://doi.org/10.1016/j.socnet.2015.02.008

Gabriel, S. L. (1990). Gender, reading, and writing: Assignments, expectations, and responses. In S. L. Gabriel \& I. Smithson (Eds.), Gender in the classroom: Power and pedagogy (pp. 127-139). Urbana, IL: University of Illinois Press.

Garvin, D. A. (2007). Teaching executives and teaching MBAs: Reflections on the case method. Academy of Management Learning \& Education, 6(3), 364-374. https://doi.org/10.5465/AMLE.2007.26361626

Gender-Career IAT. (n.d.). Retrieved May 4, 2018, from https://implicit.harvard.edu/implicit/user/agg/blindspot/indexgc.htm

Giroux, H. A. (2001). Theory and resistance in education: Towards a pedagogy for the opposition. Westport, CT: Bergin \& Garvey.

Glaser-Segura, D. A., Mudge, S., Bratianu, C., \& Dumitru, I. (2010). Development of professional identity in Romanian business students. Education Training, 52(3), 198213.

Gmür, M. (2006). The gendered stereotype of the "good manager" sex role expectations towards male and female managers. Management Revue, 17(2), 104-121.

Government of Canada, S. C. (2015, January 9). Employment by industry and sex (number in thousands). Retrieved from http://www.statcan.gc.ca/tables-tableaux/sumsom/101/cst01/labor10a-eng.htm

Graduate Admission Council. (2017). What women want: A blueprint for change in business education (pp. 1-28). USA: Graduate Management Admission Council. Retrieved from 
http://www.gmac.com/market-intelligence-and-research/research-library/diversityenrollment/what-women-want-blueprint-change-business-education

Greenwald, A. G., \& Banaji, M. R. (1995). Implicit social cognition: Attitudes, self-esteem, and stereotypes. Psychological Review, 102(1), 4-27.

Grenfell, M. (Ed.). (2008). Pierre Bourdieu: Key concepts (2nd ed.). London, UK: Routledge/Taylor \& Francis.

Grint, K. (2010). Leadership: A very short introduction. New York, NY: Oxford University Press.

Hentschel, T., Braun, S., Peus, C., \& Frey, D. (2018). The communality-bonus effect for male transformational leaders-Leadership style, gender, and promotability. European Journal of Work and Organizational Psychology, 27(1), 112-125. http://dx.doi.org.proxy1.lib.uwo.ca/10.1080/1359432X.2017.1402759

House, R., J., \& Shamir, B. (1993). Towards the integration of transformational, charismatic, and visionary theories. In M. M. Chemers \& R. Ayman (Eds.), Leadership theory and research: Perspectives and directions (pp. 81-107). San Diego, CA: Academic Press.

Ibarra, H. (1999). Provisional selves: Experimenting with image and identity in professional adaptation. Administrative Science Quarterly, 44(4), 764-791.

Ibarra, H., \& Obodaru, O. (2009, January). Women and the vision thing. Harvard Business Review, 87(1), 62-70.

Javidan, M., Bemmels, B., Devine, K., \& Dastmalchian, A. (1995). Superior and subordinate gender and the acceptance of superiors as role models. Human Relations, 48(11), 12711284. https://doi.org/10.1177/001872679504801102 
Johns, G., \& Saks, A. M. (2014). Organizational behaviour: Understanding and managing life at work (9th ed.). Toronto, ON: Pearson.

Junker, N. M., \& van Dick, R. (2014). Implicit theories in organizational settings: A systematic review and research agenda of implicit leadership and followership theories. The Leadership Quarterly, 25(6), 1154-1173. https://doi.org/10.1016/j.leaqua.2014.09.002

Kaiser, R. B., \& Wallace, W. T. (2016). Gender bias and substantive differences in ratings of leadership behavior: Toward a new narrative. Consulting Psychology Journal: Practice \& Research, 68(1), 72-98. https://doi.org/10.1037/cpb0000059

Kay, K., \& Shipman, C. (2014). The confidence code: The science and art of self-assurance what women should know (1st ed.). New York, NY: HarperBusiness.

Kelan, E. (2013). The becoming of business bodies: Gender, appearance, and leadership development. Management Learning, 44(1), 45-61.

Klikauer, T. (2015). What is managerialism? Critical Sociology, 41(7-8), 1103-1119. https://doi.org/10.1177/0896920513501351

Konrad, A., \& Shuh, A. (2013, December). Deloitte Consulting GTA: The Deloitte dads initiative. Ivey Publishing. Retrieved from https://www.iveycases.com/ProductView.aspx?id=62048

Kouzes, J. M., \& Posner, B. Z. (2012). The leadership challenge: How to make extraordinary things happen in organizations (5th ed.). San Francisco, CA: Jossey-Bass.

Lämsä, A.-M., \& Savela, T. (2014). The effect of an MBA on the development of women's management competencies: A gender viewpoint. Baltic Journal of Management, 9(2), 213-230. http://dx.doi.org.proxy1.lib.uwo.ca/10.1108/BJM-05-2013-0086 
Levy, F. (2012). Harvard Business School has the market cornered on case studies. Bloomberg Business News. Retrieved from http://www.bloomberg.com/news/articles/2015-0409/harvard-s-case-study-monopoly

Liang, N., \& Wang, J. (2004). Implicit mental models in teaching cases: An empirical study of popular MBA cases in the United States and China. Academy of Management Learning \& Education, 3(4), 397-413. https://doi.org/10.5465/AMLE.2004.15112545

Lincoln, Y. S., \& Guba, E. G. (1985). Naturalistic inquiry. Newbury Park, CA: SAGE Publications.

Lockwood, P., \& Kunda, Z. (1997). Superstars and me: Predicting the impact of role models on the self. Journal of Personality and Social Psychology, 73(1), 91-103.

Madera, J. M., Hebl, M. R., \& Martin, R. C. (2009). Gender and letters of recommendation for academia: Agentic and communal differences. Journal of Applied Psychology, 94(6), $1591-1599$.

Manuel, T., Shefte, S., \& Swiss, D. J. (1999). Suiting themselves: Women's leadership styles in today’s workplace. Cambridge, MA: Radcliffe Public Policy Institute.

Margolis, E., Soldatenko, M., Acker, S., \& Gair, M. (2001). Peekaboo: Hiding and outing the curriculum. In E. Margolis (Ed.), The hidden curriculum in higher education (pp. 1-20). New York: Routledge.

Margolis, J. A., \& Ziegert, J. C. (2016). Vertical flow of collectivistic leadership: An examination of the cascade of visionary leadership across levels. The Leadership Quarterly, 27(2), 334-348. https://doi.org/10.1016/j.leaqua.2016.01.005 
Marini, Z., Polihronis, C., \& Blackwell, W. (2010). Academic in/civility: Co-constructing the foundation for a civil learning community. Collected Essays on Learning and Teaching, 3, 89-93. https://doi.org/10.22329/celt.v3i0.3245

Mauffette-Leenders, L. A., Erskine, J. A., \& Leenders, M. R. (2007). Learning with cases (4th ed.). London, ON: Ivey Publishing.

McCabe, A. C., Ingram, R., \& Dato-on, M. C. (2006). The business of ethics and gender. Journal of Business Ethics, 64(2), 101-116. https://doi.org/10.1007/s10551-005-3327-X

McKeen, C. A., \& Burke, R. J. (1991). University initiatives for preparing managerial and professional women for work. Women in Management Review and Abstracts, 6(3), 1115. https://doi.org/10.1108/EUM0000000001798

McLean, W. P., \& Unter, K. A. (2010). Sex role stereotyping and requisite management characteristics. Economics, Management \& Financial Markets, 5(4), 127-132.

Mesny, A. (2013). Taking stock of the century-long utilization of the case method in management education. Canadian Journal of Administrative Sciences / Revue Canadienne Des Sciences de l'Administration, 30(1), 56-66. https://doi.org/10.1002/cjas.1239

Metcalfe, B., \& Linstead, A. (2003). Gendering teamwork: Re-writing the feminine. Gender, Work \& Organization, 10(1), 94-119. https://doi.org/10.1111/1468-0432.00005

Miles, M., Huberman, M., \& Saldana, J. (2013). Qualitative data analysis (3rd ed.). Thousand Oaks, CA: Sage Publications.

Mojtehedzadeh, S. (2014, December 7). MBA students at U of T dismayed by portrayal of a fictional female student who needs help from her boyfriend to evaluate job compensation packages. The Toronto Star. Retrieved from 
http://www.thestar.com/news/gta/2014/12/07/rotman_pulls_class_assignment_after_conc erns_about_sexism.html

Morse, J. (2018). Reframing rigor in qualitative inquiry. In N. K. Denzin \& Y. S. Lincoln (Eds.), The SAGE handbook of qualitative research (5th ed., pp. 796-817). Thousand Oaks, CA: SAGE Publications, Inc.

Norris, J. M., \& Wylie, A. M. (1995). Gender stereotyping of the managerial role among students in Canada and the United States. Group \& Organization Management, 20(2), $167-182$.

Offermann, L. R., Kennedy, J. K., \& Wirtz, P. W. (1994). Implicit leadership theories: Content, structure, and generalizability. The Leadership Quarterly, 5(1), 43-58. https://doi.org/10.1016/1048-9843(94)90005-1

Ottewill, R., McKenzie, G., \& Jean, L. (2005). Integration and the hidden curriculum in business education. Education \& Training, 47(2/3), 89-97.

Paris, L. D., \& Decker, D. L. (2012). Sex role stereotypes: Does business education make a difference? Gender in Management: An International Journal, 27(1), 36-50. https://doi.org/10.1108/17542411211199264

Patton, M. (2014). Qualitative research \& evaluation methods (4th ed.). Thousand Oaks, CA: Sage Publications.

Pearce, R. J. (2002). Case-based structured conflict: A means for enhancing classroom learning. Journal of Management Education, 26(6), 732-744. https://doi.org/10.1177/1052562902238327 
Petranek, C. F., Corey, S., \& Black, R. (1992). Three levels of learning in simulations: Participating, debriefing, and journal writing. Simulation \& Gaming, 23(2), 174-185. https://doi.org/10.1177/1046878192232005

Powell, G. N. (2011). The gender and leadership wars. Organizational Dynamics, 40(1), 1-9. https://doi.org/10.1016/j.orgdyn.2010.10.009

Proudfoot, D., Kay, A. C., \& Koval, C. Z. (2015). A gender bias in the attribution of creativity. Psychological Science, 26(11), 1751-1761. https://doi.org/10.1177/0956797615598739

Reid, A., Dahlgren, L. O., Petocz, P., \& Abrandt Dahlgren, M. (2008). Identity and engagement for professional formation. Studies in Higher Education, 33(6), 729-742.

Ritchhart, R., Church, M., \& Morrison, K. (2011). Making thinking visible: How to promote engagement, understanding, and independence for all learners (1st ed.). San Francisco, CA: Jossey-Bass.

Roberts, A., \& Karambayya, R. (2017). Women in management in Canada. In R. J. Burke \& A. M. Richardsen (Eds.), Women in management worldwide: Signs of progress (3rd ed., pp. 123-139). London, UK; New York, NY: Routledge.

Schein, E., \& Schein, P. (2017). Organizational culture and leadership (5th ed.). Hoboken, NJ: John Wiley and Sons, Inc.

Schein, V. E. (1973). The relationship between sex role stereotypes and requisite management characteristics. Journal of Applied Psychology, 57(2), 95-100. https://doi.org/10.1037/h0037128

Shields, S. A., MacArthur, H. J., \& McCormick, K. T. (2018). The gendering of emotion and the psychology of women. In C. B. Travis, J. W. White, A. Rutherford, W. S. Williams, S. L. Cook, \& K. F. Wyche (Eds.), APA handbook of the psychology of women: History, 
theory, and battlegrounds (Vol. 1, pp. 189-206). Washington, DC: American Psychological Association. Retrieved from https://search.proquest.com/docview/1952975820/E92BD65C0B074214PQ/1

Singh, V., Vinnicombe, S., \& Kim, J. (2006). Constructing a professional identity: How young female managers use role models. Women in Management Review, 21(1), 67-81.

Smith, C. (1997). Gender issues in management education: A new teaching resource. Women in Management Review, 12(3), 100-104. https://doi.org/10.1108/09649429710171136

Starkey, K., \& Tempest, S. (2008). A clear sense of purpose? The evolving role of the business school. Journal of Management Development, 27(4), 379-390. https://doi.org/10.1108/02621710810866732

Swiercz, P. M., \& Ross, K. (2003). Rational, human, political, and symbolic text in Harvard Business School cases: A study of structure and content. Journal of Management Education, 27(4), 407-430.

Symons, L. (2016). Writing women into business school case studies. In E. Florent-Treacy, M. Kets de Vies, R. Lehman, \& E. van de Loo (Eds.), Journeys through the organizational labryinth: A psychodynamic look at leadership identities and transitions (Vol. 1, pp. 7383). Fontainebleau, France: INSEAD.

Symons, L., \& Ibarra, H. (2014). What the scarcity of women in business case studies really looks like. Retrieved September 8, 2014, from http://blogs.hbr.org/2014/04/what-thescarcity-of-women-in-business-case-studies-really-looks-like/

The White House. (2015). Best practices for business schools to lead in expanding opportunities for women in business and to adapt to the 21st-century workforce. Washington, DC. Retrieved from 
https://obamawhitehouse.archives.gov/sites/default/files/docs/business_school_best_pract ices_final_20150805.pdf

Tietz, W. M. (2007). Women and men in accounting textbooks: Exploring the hidden curriculum. Issues in Accounting Education, 22(3), 459-480.

Valieance, E. (1983). Hiding the hidden curriculum: An interpretation of the language of justification in nineteenth-century education reform. In H. A. Giroux \& D. E. Purpel (Eds.), The hidden curriculum and moral education (pp. 9-27). Berkeley, CA: McCutchan Publishing Corp.

van Knippenberg, D., \& Stam, D. (2014). Visionary leadership. In D. V. Day (Ed.), The Oxford handbook of leadership and organizations. New York, NY: Oxford University Press. Retrieved from http://www.oxfordhandbooks.com.proxy1.lib.uwo.ca/view/10.1093/oxfordhb/978019975 5615.001.0001/oxfordhb-9780199755615-e-013

Vial, A. C., Napier, J. L., \& Brescoll, V. L. (2016). A bed of thorns: Female leaders and the selfreinforcing cycle of illegitimacy. The Leadership Quarterly, 27(3), 400-414. https://doi.org/10.1016/j.leaqua.2015.12.004

Westphal, J., \& Stern, I. (2007). Flattery will get you everywhere (especially if you are a male Caucasian): How ingratiation, boardroom behavior, and demographic minority status affect additional board appointments at U.S. companies. Academy of Management Journal, 50(2), 267-288. https://doi.org/10.5465/AMJ.2007.24634434

Yee, L., Thomas, R., Krivkovich, A., Finch, A., Kucher, E., Cooper, M., ... Konar, E. (2016). Women in the workplace 2016. McKinsey \& Co. and Lean In. Retrieved from https://womenintheworkplace.com/ 
Zenger, J., \& Folkman, J. (2012, March 15). Are women better leaders than men? Retrieved from https://hbr.org/2012/03/a-study-in-leadership-women-do 
Table 1

Composition of Gender of Protagonist

All Cases $(n=266)$

\begin{tabular}{|c|c|c|c|}
\hline$\frac{\text { Variable }}{\text { Gender }}$ & $\begin{array}{l}\text { Dimension } \\
\text { Female } \\
\text { Male }\end{array}$ & $\begin{array}{r}\frac{\#}{51} \\
215\end{array}$ & $\begin{array}{r}19 \frac{\%}{.2} \\
81.8\end{array}$ \\
\hline \multicolumn{4}{|c|}{ Within Sub-samples } \\
\hline Variable & Dimension & $\begin{array}{r}\text { Female } \\
\text { Cases } \\
(n=51)\end{array}$ & $\begin{array}{r}\text { Male } \\
\text { Cases } \\
(n=51) \\
\end{array}$ \\
\hline Case Type & $\begin{array}{l}\text { Field } \\
\text { Secondary } \\
\text { Total }\end{array}$ & $\begin{array}{r}44 \\
7 \\
51\end{array}$ & $\begin{array}{r}44 \\
7 \\
51\end{array}$ \\
\hline Firm Size $^{*}$ & $\begin{array}{l}500+\text { employees } \\
>500 \text { employees } \\
\text { Not Applicable } \\
\text { Start-up organization } \\
\text { Total }\end{array}$ & $\begin{array}{r}17 \\
30 \\
2 \\
2 \\
51\end{array}$ & $\begin{array}{r}23 \\
24 \\
0 \\
4 \\
51\end{array}$ \\
\hline Geography* & $\begin{array}{l}\text { Africa } \\
\text { Asia Pacific } \\
\text { Canada/US } \\
\text { Europe } \\
\text { Mexico, Central \& South America } \\
\text { Middle East } \\
\text { Total }\end{array}$ & $\begin{array}{r}3 \\
12 \\
23 \\
3 \\
2 \\
8 \\
51\end{array}$ & $\begin{array}{r}2 \\
19 \\
28 \\
2 \\
0 \\
0 \\
51\end{array}$ \\
\hline Industries $^{*}$ & $\begin{array}{l}\text { Accommodation \& Food } \\
\text { Agriculture, Forestry, Fishing, Hunting } \\
\text { Arts, Entertainment, Sports, Recreation } \\
\text { Construction } \\
\text { Educational Services } \\
\text { Finance, Insurance, Real Estate } \\
\text { Health Care } \\
\text { Info, Media \& Telecom } \\
\text { Manufacturing } \\
\text { Natural Resources } \\
\text { Other Services } \\
\text { Professional, Scientific, Technical Services } \\
\text { Public Administration, Government } \\
\text { Retail } \\
\text { Social Advocacy } \\
\text { Transportation \& Warehousing } \\
\text { Wholesale } \\
\text { Total }\end{array}$ & $\begin{array}{l}4 \\
0 \\
3 \\
0 \\
1 \\
2 \\
3 \\
7 \\
8 \\
2 \\
7 \\
0 \\
1 \\
3 \\
7 \\
2 \\
1 \\
51\end{array}$ & $\begin{array}{l}5 \\
1 \\
2 \\
2 \\
0 \\
1 \\
5 \\
5 \\
4 \\
2 \\
3 \\
3 \\
1 \\
8 \\
6 \\
2 \\
1 \\
51\end{array}$ \\
\hline
\end{tabular}


Table 2

Female-Dominated Pink Industries:

Female and Male Protagonists Represented in Cases

\begin{tabular}{lcccccc}
\hline Industry & $\begin{array}{c}\text { Index of } \\
\text { Female to } \\
\text { Male } \\
\text { Employment }\end{array}$ & $\begin{array}{c}\text { Cases with } \\
\text { Female } \\
\text { Protagonists } \\
\text { (N=51) }\end{array}$ & $\begin{array}{c}\text { \% of Cases } \\
\text { with Female } \\
\text { Protagonists }\end{array}$ & $\begin{array}{c}\text { Cases with } \\
\text { Male } \\
\text { Protagonists } \\
\text { (N=215) }\end{array}$ & $\begin{array}{c}\text { \% of Cases } \\
\text { with Male } \\
\text { Protagonists }\end{array}$ & $\begin{array}{c}\text { Index of } \\
\text { Female to } \\
\text { Males in } \\
\text { Cases }^{* *}\end{array}$ \\
\hline $\begin{array}{l}\text { Educational } \\
\text { Services }\end{array}$ & 212.5 & 2 & 3.9 & 3 & 1.4 & 280 \\
$\begin{array}{l}\text { Food \& } \\
\text { Hospitality }\end{array}$ & 147.7 & 3 & 5.9 & 13 & 6.0 & 98 \\
Health Care & 460.6 & 3 & 5.9 & 5 & 2.3 & 256 \\
Retail & 130.4 & 4 & 7.8 & 27 & 12.4 & 63 \\
Social Advocacy & 460.6 & 8 & 15.7 & 23 & 10.5 & 149 \\
Total & $\mathrm{n} / \mathrm{a}$ & 20 & 39.2 & 71 & 32.3 & 121
\end{tabular}

* Scores $>100$ indicate overrepresentation of women employed in a specific industry.

${ }^{* *}$ Scores $>100$ indicate overrepresentation of women protagonists in cases in a specific industry.

Sources:

Government of Canada, S. C. (2015, January 9). Employment by industry and sex (number in thousands). Retrieved from http://www.statcan.gc.ca/tables-tableaux/sumsom/101/cst01/labor10a-eng.htm

The 20 most common occupations among men aged 15 years and over and the proportion of men in the total workforce, May 2011. (2013, June 13). Statistics Canada, Government of Canada. Retrieved from http://www12.statcan.gc.ca/nhs-enm/2011/as-sa/99-012x/2011002/tbl/tbl03-eng.cfm 
Table 3

Gender of Characters

\begin{tabular}{lrrr}
\hline & $\begin{array}{c}\text { Gender of } \\
\text { Protagonist }\end{array}$ & $\begin{array}{r}\text { Ratio of } \\
\text { Females to } \\
\text { Males }\end{array}$ \\
\hline Protagonist Solo & Female & Male & 0.58 \\
Protagonist \& Female Co-Protagonist & 19 & 33 & 0.40 \\
Protagonist \& Male Co-Protagonist & 6 & 15 & 3.00 \\
Protagonist \& Other Female Character & 9 & 3 & NA \\
Protagonist \& Other Male Character & 3 & 0 & NA \\
Protagonist \& Other Mixed Character & 8 & 0 & NA \\
Total & 6 & 0 & 1.00
\end{tabular}

* Male equals 1.0. For example, the ratio of female sole protagonist to male sole protagonist is 0.58:1.00. 
Table 4

Description of Other Characters in Case

\begin{tabular}{|c|c|c|c|}
\hline Description of Other Female Characters & Female & $\begin{array}{l}\text { ender of } \\
\text { tagonist }\end{array}$ & $\begin{array}{r}\text { Ratio of } \\
\text { Females to } \\
\text { Males }\end{array}$ \\
\hline \# cases & 25 & 14 & 1.79 \\
\hline \# references & 84 & 30 & 2.80 \\
\hline Mean $\%$ case coverage ${ }^{1}$ & $1.63 \%$ & $0.91 \%$ & 1.79 \\
\hline \multicolumn{4}{|l|}{ Description of Other Male Characters } \\
\hline \# cases & 35 & 31 & 1.13 \\
\hline \# references & 158 & 74 & 2.14 \\
\hline Mean $\%$ case coverage & $1.57 \%$ & $0.88 \%$ & 1.78 \\
\hline
\end{tabular}

${ }^{1}$ Percent case coverage is calculated as follows: the number of words coded to the variable as a percentage of the number of words in the case. Higher \% case coverage indicates a greater proportion of the case devoted to that variable, and thus suggests that the author puts greater emphasis on that variable. Mean \% case coverage is the average case coverage across all cases in the sample. 
Table 5

Direct Quotations

\begin{tabular}{|c|c|c|c|}
\hline Variable & Female & $\begin{array}{l}\text { nder of } \\
\text { agonist }\end{array}$ & $\begin{array}{r}\text { Ratio of } \\
\text { Females to } \\
\text { Males }\end{array}$ \\
\hline \multicolumn{4}{|l|}{ Primary Protagonist } \\
\hline \# cases with quotations & $26^{*}$ & 30 & 0.87 \\
\hline \# quotations & 126 & 173 & 0.73 \\
\hline Mean $\%$ case coverage & $1.42 \%$ & $2.59 \%$ & 0.55 \\
\hline \multicolumn{4}{|l|}{ Secondary Protagonist } \\
\hline \# cases with quotations & 3 & 1 & 3.00 \\
\hline \# quotations & 5 & 12 & 0.42 \\
\hline Mean $\%$ case coverage & $0.54 \%$ & $2.35 \%$ & 0.23 \\
\hline \multicolumn{4}{|l|}{ Other Female Character } \\
\hline \# cases with quotations & 16 & 7 & 2.29 \\
\hline \# quotations & 37 & 19 & 1.95 \\
\hline Mean $\%$ case coverage & $0.90 \%$ & $0.78 \%$ & 1.15 \\
\hline \multicolumn{4}{|l|}{ Other Male Character } \\
\hline \# cases with quotations & 24 & 21 & 1.14 \\
\hline \# quotations & 105 & 63 & 1.67 \\
\hline Mean $\%$ case coverage & $1.28 \%$ & $1.11 \%$ & 1.15 \\
\hline
\end{tabular}

Note: the female cases exclude one outlier (Amisha Gupta), which at 25\% quotations skewed the \% case coverage. 
Table 6

References to Protagonist's Team

\begin{tabular}{lrrr}
\hline & Gender of Protagonist & $\begin{array}{r}\text { Ratio of } \\
\text { Females to } \\
\text { Males }\end{array}$ \\
\hline And His or And Her Team & Female & Male & 0.76 \\
\# cases & 13 & 17 & 1.36 \\
\# references & 53 & 39 & 2.85 \\
Mean \% case coverage & $0.37 \%$ & $0.13 \%$ & \\
\hline
\end{tabular}




\section{Table 7}

Vision, Mission, and Strategic Objectives

\begin{tabular}{lrrr}
\hline & \multicolumn{2}{l}{ Gender of Protagonist } & $\begin{array}{r}\text { Ratio of } \\
\text { Females to } \\
\text { Males }\end{array}$ \\
\hline Attributed to Primary Protagonist & Female & Male & \\
\hline \# cases & & & 0.91 \\
\# references & 20 & 22 & 1.25 \\
$\quad$ Mean \% case coverage & 55 & 44 & 0.55 \\
Attributed to Organization & $0.79 \%$ & $1.43 \%$ & 0.45 \\
\# cases & & & 22 \\
\# references & 10 & 41 & 0.41 \\
Mean \% case coverage & 17 & $0.39 \%$ & 2.28 \\
\hline
\end{tabular}


Table 8

Elements of Vision

\begin{tabular}{|c|c|c|c|}
\hline & \multicolumn{2}{|c|}{ Gender of Protagonist } & \multirow[b]{2}{*}{$\begin{array}{r}\text { Ratio of } \\
\text { Females to } \\
\text { Males } \\
\end{array}$} \\
\hline & Female & Male & \\
\hline \multicolumn{4}{|l|}{ Innovative and Creative } \\
\hline \# cases & 19 & 12 & 1.58 \\
\hline \# references & 54 & 27 & 2.00 \\
\hline Mean $\%$ case coverage & $0.60 \%$ & $1.02 \%$ & 0.59 \\
\hline \multicolumn{4}{|l|}{ Intuition and Sensing } \\
\hline \# cases & 20 & 25 & 0.80 \\
\hline \# references & 43 & 64 & 0.67 \\
\hline Mean \% case coverage & $0.56 \%$ & $0.44 \%$ & 1.27 \\
\hline \multicolumn{4}{|l|}{ Passion and Dreams } \\
\hline \# cases & 18 & 20 & 0.90 \\
\hline \# references & 39 & 85 & 0.46 \\
\hline Mean \% case coverage & $0.43 \%$ & $1.51 \%$ & 0.28 \\
\hline
\end{tabular}


Table 9

Representations of Power

\begin{tabular}{|c|c|c|c|}
\hline & Female & $\begin{array}{l}\text { nder of } \\
\text { agonist }\end{array}$ & $\begin{array}{r}\text { Ratio of } \\
\text { Females to } \\
\text { Males }\end{array}$ \\
\hline \multicolumn{4}{|l|}{ Coercive } \\
\hline \# cases & 1 & 0 & $\mathrm{~N} / \mathrm{A}$ \\
\hline \# references & 2 & 0 & $\mathrm{~N} / \mathrm{A}$ \\
\hline Mean $\%$ case coverage & $0.47 \%$ & 0 & $\mathrm{~N} / \mathrm{A}$ \\
\hline \multicolumn{4}{|l|}{ Empowers Others } \\
\hline \# cases & 7 & 2 & 3.50 \\
\hline \# references & 9 & 3 & 3.00 \\
\hline Mean \% case coverage & $0.40 \%$ & $0.23 \%$ & 1.74 \\
\hline \multicolumn{4}{|l|}{ Expert } \\
\hline \# cases & 5 & 43 & 0.12 \\
\hline \# references & 8 & 69 & 0.12 \\
\hline Mean $\%$ case coverage & $0.68 \%$ & $0.37 \%$ & 1.84 \\
\hline \multicolumn{4}{|l|}{ Legitimate } \\
\hline \# cases & 2 & 48 & 0.04 \\
\hline \# references & 2 & 65 & 0.03 \\
\hline Mean \% case coverage & $0.38 \%$ & $0.27 \%$ & 1.41 \\
\hline \multicolumn{4}{|l|}{ Limited or No Power } \\
\hline \# cases & 2 & 1 & 2.00 \\
\hline \# references & 2 & 1 & 2.00 \\
\hline Mean \% case coverage & $0.22 \%$ & $2.22 \%$ & 0.10 \\
\hline \multicolumn{4}{|l|}{ Referent } \\
\hline \# cases & 0 & 3 & 0.00 \\
\hline \# references & 0 & 5 & 0.00 \\
\hline Mean $\%$ case coverage & 0 & $0.25 \%$ & 0.00 \\
\hline \multicolumn{4}{|l|}{ Reputational } \\
\hline \# cases & 10 & 13 & 0.77 \\
\hline \# references & 20 & 30 & 0.67 \\
\hline Mean $\%$ case coverage & $0.94 \%$ & $0.47 \%$ & 2.00 \\
\hline
\end{tabular}


Table 10

Representation of Leadership Characteristics

\begin{tabular}{|c|c|c|c|}
\hline \multirow[b]{2}{*}{ Variable } & \multicolumn{2}{|c|}{ Gender of Protagonist } & \multirow[b]{2}{*}{$\begin{array}{r}\text { Ratio of } \\
\text { Females to } \\
\text { Males }\end{array}$} \\
\hline & $\begin{array}{r}\text { Female } \\
\text { Cases }\end{array}$ & $\begin{array}{r}\text { Male } \\
\text { Cases }\end{array}$ & \\
\hline \multicolumn{4}{|l|}{ Leader } \\
\hline \# cases & 13 & 12 & 1.08 \\
\hline \# references & 22 & 15 & 1.47 \\
\hline Mean $\%$ case coverage & $0.29 \%$ & $0.65 \%$ & 0.45 \\
\hline \multicolumn{4}{|c|}{ Rational, Decisive, Evidence Based } \\
\hline \# cases & 33 & 32 & 1.03 \\
\hline \# references & 104 & 128 & 0.81 \\
\hline Mean \% case coverage & $0.98 \%$ & $1.65 \%$ & 0.59 \\
\hline \multicolumn{4}{|l|}{ Risk-Taking } \\
\hline \# cases & 8 & 5 & 1.60 \\
\hline \# references & 16 & 20 & 0.80 \\
\hline Mean $\%$ case coverage & $0.53 \%$ & $0.81 \%$ & 0.65 \\
\hline \multicolumn{4}{|l|}{ Risk Averse } \\
\hline \# cases & 4 & 1 & 4.00 \\
\hline \# references & 4 & 1 & 4.00 \\
\hline Mean $\%$ case coverage & $0.20 \%$ & $0.06 \%$ & 3.33 \\
\hline \multicolumn{4}{|l|}{ Intuition and Sensing } \\
\hline \# cases & 20 & 25 & 0.80 \\
\hline \# references & 43 & 64 & 0.67 \\
\hline Mean $\%$ case coverage & $0.56 \%$ & $0.44 \%$ & 1.27 \\
\hline
\end{tabular}


Table 11

Representation of Collaborative Behavior

\begin{tabular}{|c|c|c|c|}
\hline Variable & \multicolumn{2}{|c|}{$\begin{array}{r}\text { Gender of } \\
\text { Protagonist }\end{array}$} & $\begin{array}{r}\text { Ratio of } \\
\text { Females to } \\
\text { Males }\end{array}$ \\
\hline \multicolumn{4}{|l|}{ Total Collaboration } \\
\hline \# cases with quotations & 21 & 28 & 0.75 \\
\hline \# quotations & 40 & 105 & 0.38 \\
\hline Mean \% case coverage & $0.42 \%$ & $0.76 \%$ & 0.55 \\
\hline \multicolumn{4}{|l|}{ Interpersonal } \\
\hline \# cases with quotations & 15 & 14 & 1.07 \\
\hline \# quotations & 29 & 28 & 1.04 \\
\hline Mean $\%$ case coverage & $0.39 \%$ & $0.46 \%$ & 0.85 \\
\hline \multicolumn{4}{|l|}{ Intraorganizational } \\
\hline \# cases with quotations & 3 & 6 & 0.50 \\
\hline \# quotations & 3 & 9 & 0.33 \\
\hline Mean \% case coverage & $0.15 \%$ & $0.24 \%$ & 0.63 \\
\hline \multicolumn{4}{|l|}{ Inter-Organizational } \\
\hline \# cases with quotations & 8 & 26 & 0.31 \\
\hline \# quotations & 12 & 67 & 0.18 \\
\hline Mean $\%$ case coverage & $0.32 \%$ & $0.56 \%$ & 0.57 \\
\hline
\end{tabular}

Note: the female cases exclude one outlier (Amisha Gupta), which at 25\% quotations skewed the $\%$ case coverage. 
Table 12

Representations of Agentic Behavior

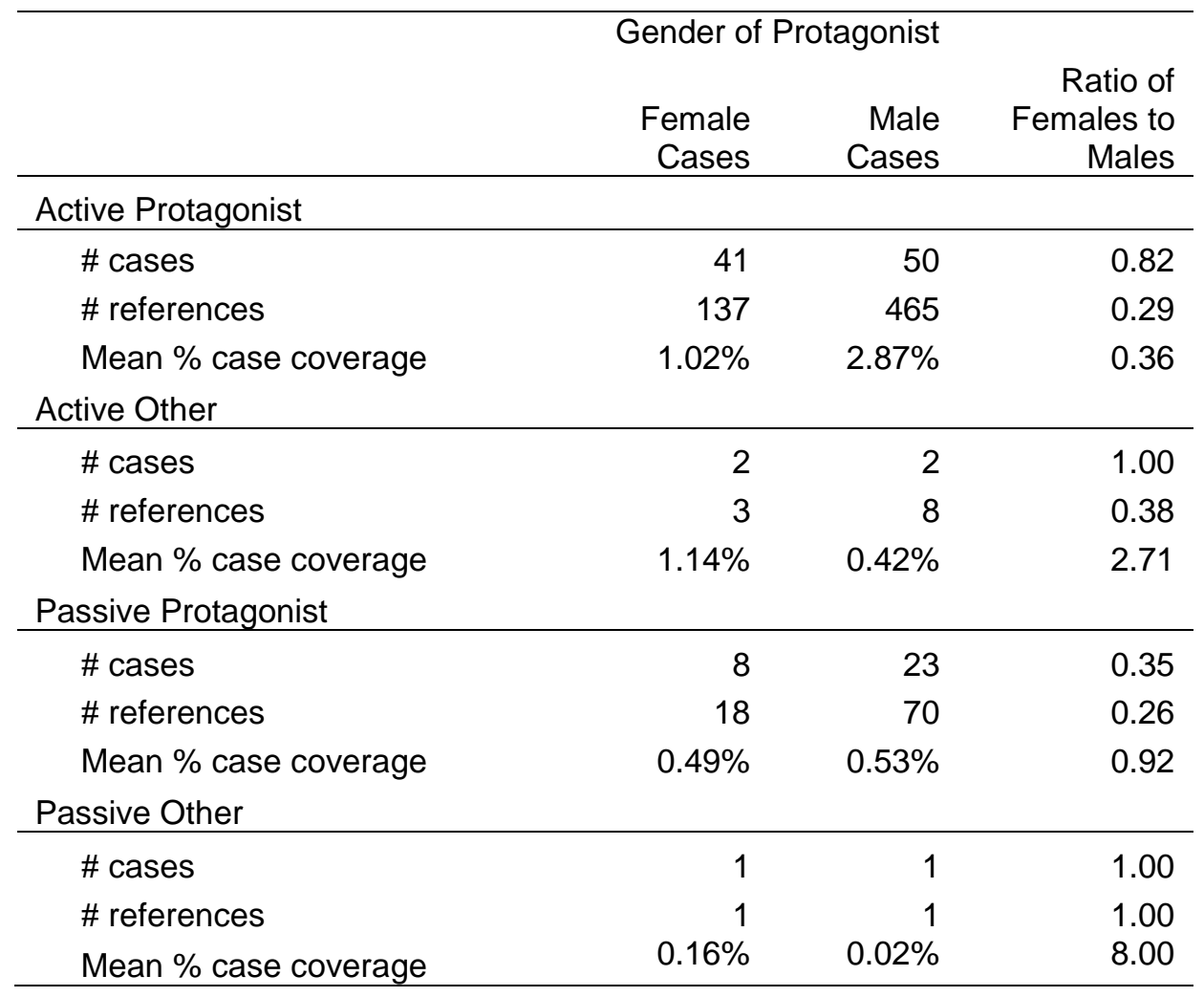


Table 13

Representations of Crucible Experience

\begin{tabular}{|c|c|c|c|}
\hline & \multicolumn{2}{|c|}{ Gender of Protagonist } & \multirow[b]{2}{*}{$\begin{array}{r}\text { Ratio of } \\
\text { Females to } \\
\text { Males } \\
\end{array}$} \\
\hline & Female & Male & \\
\hline \multicolumn{4}{|l|}{ Total Crucible Experiences } \\
\hline \# cases & 13 & 21 & 0.62 \\
\hline \# references & 17 & 52 & 0.33 \\
\hline Mean $\%$ case coverage & $1.44 \%$ & $1.46 \%$ & 0.99 \\
\hline \multicolumn{4}{|l|}{ CSR } \\
\hline \# cases & 0 & 3 & 0.00 \\
\hline \# references & 0 & 7 & 0.00 \\
\hline Mean \% case coverage & 0 & $2.86 \%$ & 0.00 \\
\hline \multicolumn{4}{|l|}{ For Profit } \\
\hline \# cases & 8 & 7 & 1.14 \\
\hline \# references & 10 & 11 & 0.91 \\
\hline Mean \% case coverage & $1.63 \%$ & $1.93 \%$ & 0.84 \\
\hline \multicolumn{4}{|l|}{ Non-Profit } \\
\hline \# cases & 3 & 10 & 0.30 \\
\hline \# references & 4 & 25 & 0.16 \\
\hline Mean \% case coverage & $1.28 \%$ & $1.35 \%$ & 0.95 \\
\hline \multicolumn{4}{|l|}{ Social Enterprise } \\
\hline \# cases & 2 & 7 & 0.29 \\
\hline \# references & 3 & 8 & 0.38 \\
\hline Mean $\%$ case coverage & $0.91 \%$ & $0.57 \%$ & 1.60 \\
\hline
\end{tabular}


Table 14

Representations of Personal Characteristics

\begin{tabular}{|c|c|c|c|c|}
\hline \multirow{2}{*}{ Variable } & & \multicolumn{2}{|c|}{ Gender of Protagonist } & \multirow[b]{2}{*}{$\begin{array}{r}\text { Ratio of } \\
\text { Females to } \\
\text { Males } \\
\end{array}$} \\
\hline & & Female Cases & Male Cases & \\
\hline \multicolumn{5}{|l|}{ Cautious } \\
\hline & \# cases & 11 & 6 & 1.83 \\
\hline & \# references & 15 & 6 & 2.50 \\
\hline & Mean $\%$ case coverage & $0.27 \%$ & $0.10 \%$ & 2.70 \\
\hline \multicolumn{5}{|l|}{ Certitude } \\
\hline \multicolumn{5}{|l|}{ Certain } \\
\hline & \# cases & 40 & 46 & 0.87 \\
\hline & \# references & 125 & 359 & 0.35 \\
\hline & Mean $\%$ case coverage & $0.90 \%$ & $1.88 \%$ & 0.48 \\
\hline \multicolumn{5}{|l|}{ Uncertain } \\
\hline & $\#$ cases & 25 & 35 & 0.71 \\
\hline & \# references & 50 & 155 & 0.32 \\
\hline & Mean $\%$ case coverage & $0.59 \%$ & $0.74 \%$ & 0.80 \\
\hline \multicolumn{5}{|l|}{ Emotions } \\
\hline \multicolumn{5}{|l|}{ Emotional } \\
\hline & \# cases & 27 & 14 & 1.93 \\
\hline & \# references & 98 & 34 & 2.88 \\
\hline & Mean $\%$ case coverage & $0.74 \%$ & $0.56 \%$ & 1.32 \\
\hline \multicolumn{5}{|c|}{ Needing Emotional Support } \\
\hline & \# cases & 3 & 2 & 1.50 \\
\hline & \# references & 8 & 4 & 2.00 \\
\hline & Mean $\%$ case coverage & $0.94 \%$ & $0.85 \%$ & 1.11 \\
\hline \multicolumn{5}{|c|}{ Overwhelmed } \\
\hline & \# cases & 8 & 8 & 1.00 \\
\hline & \# references & 18 & 10 & 1.80 \\
\hline & Mean $\%$ case coverage & $0.53 \%$ & $0.16 \%$ & 3.31 \\
\hline \multicolumn{5}{|c|}{ Ethics and Values } \\
\hline & \# cases & 4 & 13 & 0.31 \\
\hline & \# references & 11 & 20 & 0.55 \\
\hline & Mean $\%$ case coverage & $1.22 \%$ & $0.16 \%$ & 7.63 \\
\hline \multicolumn{5}{|l|}{ Aggressive } \\
\hline & $\#$ cases & 12 & 8 & 1.50 \\
\hline & \# references & 24 & 12 & 2.00 \\
\hline & Mean $\%$ case coverage & $1.44 \%$ & $0.41 \%$ & 3.51 \\
\hline \multicolumn{5}{|c|}{ Detail Oriented } \\
\hline & \# cases & 19 & 11 & 1.73 \\
\hline
\end{tabular}




\begin{tabular}{crrr} 
\# references & 33 & 16 & 2.06 \\
Mean \% case coverage & $0.41 \%$ & $0.47 \%$ & 0.87 \\
Quality Oriented & & & \\
\hline \# cases & 10 & 7 & 1.43 \\
$\quad$ \# references & 27 & 19 & 1.42 \\
$\quad$ Mean \% case coverage & $0.60 \%$ & $0.43 \%$ & 1.40 \\
Credible $\quad$ & & 7 & \\
\hline$\quad$ \# cases & 25 & 9.57 & 5.33 \\
$\quad$ \# references & 48 & $0.18 \%$ & 5.44 \\
$\quad$ Mean \% case coverage & $0.98 \%$ & & \\
\hline Lacking Credibility & & 0 & NA \\
\# cases & 12 & 0 & NA \\
\# references & 21 & $0.0 \%$ & NA \\
\hline Mean \% case coverage & & &
\end{tabular}


Appendix A

Female Cases in Sample

All Cases Sourced from Ivey Publishing include Product Number

Agarwal, S. (2013). Tehelika in crisis. 9B14M081.

Alon, I., Dugosh, J., \& Lohwasser, M. (2014). Israeli wines in China: Reaching for new heights. 9B14M006.

Alon, I., Wang, H., Dugosh, J., \& Oberdorf, K. (2014). Dialogue in the dark: Social enterprise in China. 9B14M014.

Apaydin M., Mostafa A., Mohamed Sherin, M., Ali Mobarak, M., Mohsen Fahmy, A., \& Labib, D. (2014a). Azza Fahmy Jewellery: International expansion. 9B13M099.

Apaydin M., Mostafa, A., Mohamed Sherin, M., Mobarak, M., Fahmy, A., \& Labib, D. (2014b). Azza Fahmy Jewellery: Restructuring a successful startup. 9B13M097.

Apaydin M., Mostafa, A., Mohamed Sherin, M., Mobarak, M., Mohsen Fahmy, A., \& Labib, D. (2014c). Azza Fahmy Jewellery: Expand locally or internationally? 9B13M098.

Apaydin, M., Mostafa, H., \& Khauli, L. (2014d). Azza Fahmy Jewellery: Going online post revolution $(A)$. 9B14M023.

Apaydin, M., Mostafa, H., \& Khauli, L. (2014e). Azza Fahmy Jewellery: Going online post revolution $(B)$. 9B14M024.

Avadhanam, R., \& Pidikiti, J. (2014). ALEAP: A leap of faith for women entrepreneurs. 9B14M090.

Bastian, B. (2014). Inaash: Bridging the chasm between nonprofit objectives and long term financial profitability. 9B14M004.

Boothe, P. (2014). Environment Canada. 9B14M011.

Branzei, O., Lin, H., \& Chakravarty, D. (2014). WWF's living planet at work: Championed by HP. 9B14M014.

Chandrasekhar, R. (2014). Xerox Innovation Group - From products to services. 9B14M034.

Chaudhri, V., \& Kaul, A. (2014). IBM India: Localizing a global model of corporate citizenship. 9B14C020.

Chia, E., \& Chu, S. (2014). Denka Chemicals. 9B14E007.

Conway Dato-on, M. (2014). Fundación Bringas Hahgenbeck (FBH): Serving the needs of Mexican senior citizens. 9B14A005.

Cornhill, A. (2014). Mistral Energy: A tale of two power markets. 9B14E011.

Daouk-Oyry, L., \& Jamali, D. (2013). Shankaboot: Extending the web series from Lebanon to other Arab countries. 9B13M106.

Eaton, C., Hunt, W., \& Smart, M. (2014). Helio Polymer Enterprises. 9B14D002.

Eccleston, G. (2014). HudBay Minerals: Acquisition of Norsemont Mining. 9B14N013.

Funk, T., \& Lange-Faria, W. (2014). Le Cerf de Tremblant. 9B13A037.

Hae, R. (2014). Korra Dancewear. 9B14A011.

Hawarden, V., Sutherland, M., \& Prangley, A. (2013). Tackling the HIV/AIDS pandemic through multipartner stakeholder engagement. 9B13C029.

Heimeriks, K., Gunther, M., \& Lelieveld, M. (2014). Lighting up Philips' Asian entertainment activities (B). 9B14M019.

House, D. (2014). Complete service billing. 9B14M023.

Huang, K. (2014). Indigo Books and Music Inc. 9B14N008. 
Jarosinski, M. (2014). Burberry. 9B14A014.

Jayakumar, T., Ray, N., Mulanjur, D., Basu, D., \& Patkar, G. (2014). Sudarshan Chemicals India: Crowd-sourcing for corporate sustainability. 9B14M065.

Jean, M. (2013). Sweet Leaf Bath Co. 9B13A004.

Keynon, K. (2013). Can Facebook save our furry friends? 9B13A031.

Korman, D., Liu, I., \& Xie, S. (2014). Lilgaa Property Management: Property investing in Eldoret, Kenya. 9B14M043.

Laszlo, C., \& Briggs, A. (2013). La Vaca Independiente: Should a social enterprise adopt a forprofit business model? 9B13C033.

Leithwood, M. (2013). SOJO: Modelling social enterprise. 9B14M023.

Maamoun, A. (2014). Lake Superior Lodge: It's not always about “Location, location, location." 9B14A007.

Marcolin. L. (2014). Hustream Technologies interactive video. 9B14E008.

Mark, K. (2014). Harlequin Enterprises: Assessing e-books. 9B14M027.

Neal, C., \& Karim, S. (2014). A student's dilemma: Rent or buy? 9B14E013.

Pandey, N., \& Singh, G. (2014). Ludhiana City Bus Services Limited: Pricing for profits. 9B14A019.

Qi, M., \& Demeester, L. (2014). Monnikenheide. 9B13D020.

Ross, C., \& McKenzie, D. (2014). The Montreal Stars. 9B14A043.

Saganski, M. (2013). Sarah Vickers: Post acquisition career management. 9B13C015.

Shah, S., Sankar, A., \& Sharp, D. (2014). Hindustan Unilever Ltd.: Meeting employee expectations. 9B13C036.

Sharma, G., \& Ghatge, I. (2013). Ford Motor Company: New shades of green through soy foam. 9B13M109.

Sharma, G., \& Hyatt, D.G. (2013). Taj Hotels: Building sustainable livelihoods. 9B13C032.

Shuh, A. (2014). Cole and Parker: Socks that start businesses. 9B14A006.

Smith, A., \& Cram, H. (2014). Sickkids in Qatar-Responding to a request for proposal. 9B14M025.

Tatachari, S. (2014). Amisha Gupta's first year at work. 9B14C002.

Thomson, M., Goldberg, E., Gottlieb, B., Landy, S., Solomon, S., \& Sittler, L. (2014). Dove Real Beauty sketches campaign. 9B14A012.

Tsui, A., \& Cheung, R. (2014). Diamond Cab: An investment of a philanthropy fund. 9B13M077.

Venkatesh, S., \& Bhatia, S. (2013). 7-Eleven in Thailand. 9B13B021.

Zolf. J. (2014). Jill's Table: Digitizing a retail legacy. 9B14A002. 
Appendix B

Male Cases in Sample

Agarwal, R., D'Souza, K., \& Kumbluvelil, A.J. (2014). AGV: Crisis at the top. 9B14C008.

Aggarwal, A., Kamath, R., \& Rao, S. (2013) Evoe Spring Spa: A positioning dilemma. 9B13A051.

Alvi, F.H. (2014). Vice Media: Competitive advantage and global expansion. 9B14M039.

Austin, R.D., Minbaeva, D., \& Schafer, S. (2014). Tokyo Jane. 9B14M085.

Ayensu, F., Haggerty, N., Faircloth, J., Fisher, H., \& MacNicol, D. (2014). Scuby's Enterprises: Starting a business in Ghana. 9B14M041.

Bell, P., Bedminster, S., \& Onianwah, R. (2013). My School Bus. 9B13E016.

Bhatnagar, J., Sharma, N., \& Gupta, N. (2013). The Indian greenpreneur: Management of frenemy talent and coopetition. 9B13C028.

Boon, R., Campbell, C., \& Pitt, L. (2014). Nespresso and the U.S. market. 9B14M080.

Boothe, P., Dicerni, R., \& Lyons, C. (2014). FedDev Ontario. 9B14M010.

Branzei, O., \& Hu, Y. (2013). NPI in China: Organizing for social good. 9B13M122.

Dawar, D., \& Chandrasekhar, R. (2014). Dlight Design. 9B14A023.

Dunbar, C., \& Hatch, D. (2013). Inmet Mining Corporation: Corporate bond issuance. 9B13N021.

Dutta, D., \& Manimala, M.J. (2014). Eyes of Janus: Evaluating learning and development at Tata Motors. 9B14C034.

Gillett, M., Sturby, C., \& Bowden, L. (2014). Loblaw and Shoppers Drug Mart. 9B14B003.

Surie, G. (2013). Kalamandir: Creating an ecosystem for livelihood generation. 9B13M080.

Goyal, S., \& Kapoor, A. (2013). Diversey in India: The growth challenges and options. 9B13M115.

Goyal, S., Kapoor, A., \& Gupta, R. (2014). Boond: Enabling access to energy solutions for rural India. 9B14M048.

Grasby, E, \& Finnbogason, C. (2013). MacKenzie \& Marr Guitars. 9B13A038.

Grasby, E. \& Miller, A. J. (2014). Wacky Webster's TV \& Home Audio. 9B14B008

Grasby, E., \& Ian Dunn, I. (2014). Hockley Valley Brewing Co. Inc. 9B14B006.

Grasby, E., \& Shuh, A. (2014). Mama J's Marmalade. 9B14B002.

Haggerty, N., Hernden, D., \& Wang, A. (2013) Rawanda Backpackers. 9B13A046.

Jagadale, S., \& Maitra, D. (2014). Bandhan Microfinance: Is transformation to bank status required? 9B14N019.

Joshi, C., Bapuji, H., \& Chandrasekhar, R. (2013). Windermere Manor: Sustainability and change. 9B13C044.

Konrad, A., \& Shuh, A. (2013). Deloitte Consulting GTA: The Deloitte dads initiative. 9B13C046.

Laszlo, C., Briggs, A., \& Potdar, J. (2013). GOJO Industries: Aiming for global sustainability leadership. 9B13M108.

Lee, S. H., Cotte, J., \& Blanchard, D. (2014). Abercrombie \& Fitch: Is it unethical to be exclusive? 9B14A009.

Mehrotra, S., \& Pereira, A. (2014). Manjushree Technopak Limited. 9B14M074.

Mehrotra, S.U., \& Rangan, S. (2014). Robert Bosch Engineering India: Plotting a growth strategy. 9B14M099. 
Moroz, P., Parker, S., \& Gamble, E. (2014). Growing Tentree: Social enterprise, social media and environmental sustainability. 9B14M030.

Mulholland, R. (2013). The Kinkajou Bottle Cutter. 9B13A034.

Pandit, D., \& Sahay, A. (2013). Nurturing Green: The growth dilemma (C). 9B13M081.

Parkin, M., Bigus, P., \& Tekriwal, S. (2013). Movember: More mo sistas. 9B13M086.

Petersen, B., Nikerle-Uhthoff, D., \& Schwaerzler, H. (2014). SAP: The challenge of aligning sourcing and innovation strategies. 9B14M101.

Pirouz, R., \& Mark, K. (2014). Customer segmentation and business model evolution at Unbounce. 9B14A029.

Raffety, R., \& Branzei, O. (2013). Wellspring (A): Partnering for compassion. 9B13M131.

Raggio, R. and Eubanks, B. (2013). Michael Shaps Winery: Evaluating the "Custom Crush" Opportunity. 9B13A027.

Raghavan, S. (2014). Reboot Systems' refurbished computers: A frugal solution for digital divide. 9B14M089.

Rowe, G., \& Prashad, S. (2013). ORNGE: A crisis at Ontario's air ambulance service. 9B13C005.

Roy, D., \& Bandyopadhyay, A. (2014). K M Trans Logistics: Workshop operations. 9B14D009.

Sandeep, P. (2013). Ajanta Packaging. 9B13A049.

Sider, M., \& Bloomfield, R. (2014). Escapes Outdoor Living Designs Inc. 9B14M044.

Snowdon, A., Schnarr, K., \& Kunsch, A. (2014). Organizational transformation at the Centre for Addiction and Mental Health. 9B14M083.

Snowdon, A., Smith, A., \& Cramm, H. (2013). Strongest Families. 9B13M133.

Sondhi, N, \& Singhvi, S. (2013). Safe Water Network in India. 9B13A047.

Subramanian, R. (2014). SodaStream takes on Coke and Pepsi. 9B14M038.

Swaminathan, T. N., \& Thamizhvanan, A. (2013). Jade Magnet: Creating a crowdsourcing enterprise. 9B13M085.

Thomson, M. \& Meagher, I. (2013) The Ontario Hockey League. 9B13A028.

Weil, M., \& Rao, C. (2014). Dovercourt Recreation Centre - healing a rift. 9B14C039.

Yadav, A., \& Ashra, S. (2013). Harmonizing demand forecasting and supply at Mahindra \& Mahindra, Ltd. 9B13D019.

Yan, X., MacFayden, M., \& Morden, M. (2014). getClarity Inc. (A). 9B14E015. 


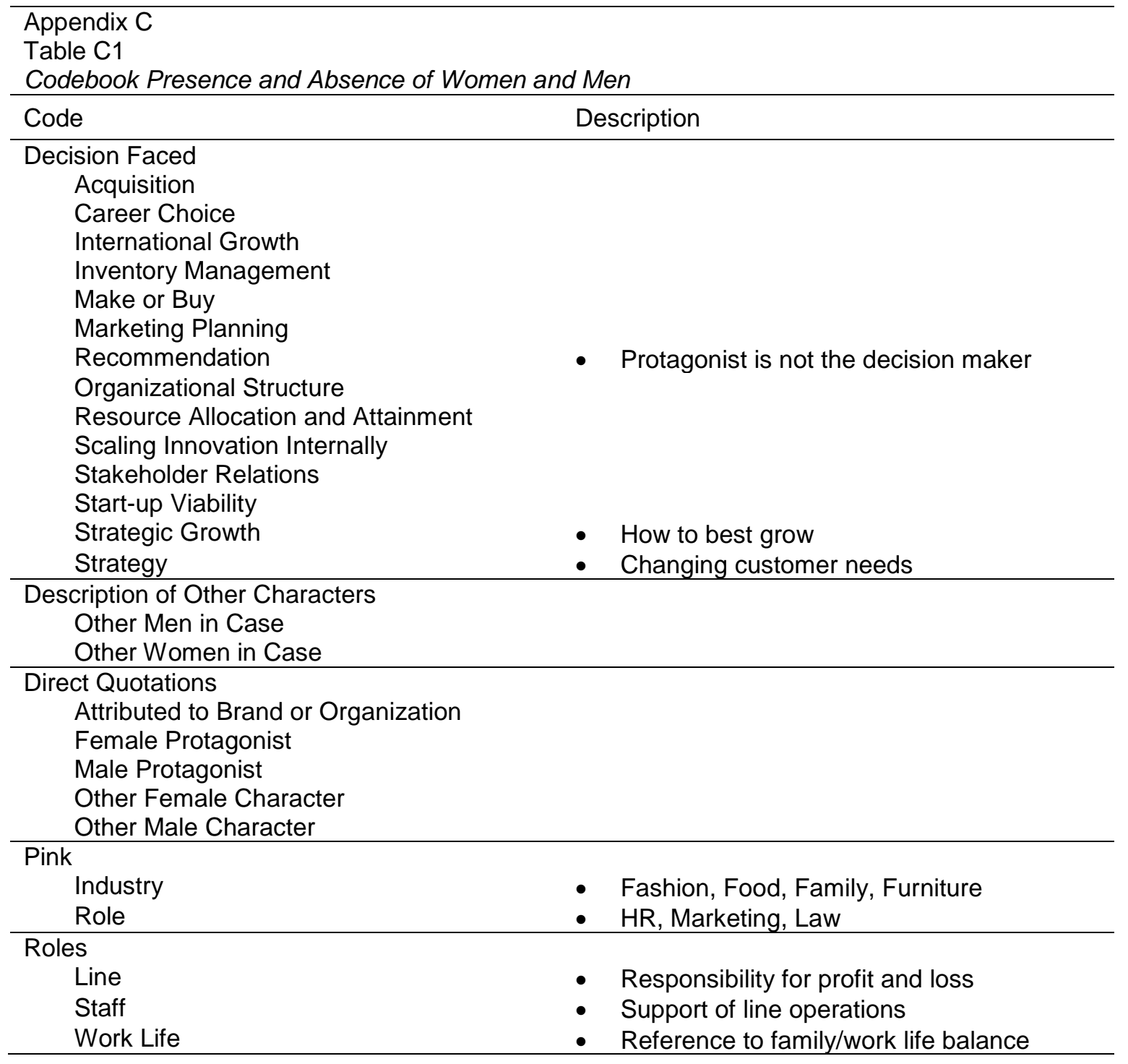




\begin{tabular}{|c|c|}
\hline \multicolumn{2}{|c|}{$\begin{array}{l}\text { Appendix C } \\
\text { Table C2 } \\
\text { Codebook Representation of Personal Characteristics }\end{array}$} \\
\hline Code & Description \\
\hline Aggressive & $\begin{array}{l}\text { Driven, not satisfied, determined, } \\
\text { confronted, intense }\end{array}$ \\
\hline Brave & - Brave, fearless \\
\hline \multicolumn{2}{|l|}{$\begin{array}{l}\text { Certainty } \\
\text { Uncertainty }\end{array}$} \\
\hline Cautious & Slow, careful, hesitant, shy \\
\hline \multicolumn{2}{|l|}{ Credibility } \\
\hline $\begin{array}{l}\text { Credible } \\
\text { Lack of Credibility }\end{array}$ & $\begin{array}{l}\text { - Competent, experienced, knowledgeable } \\
\text { - Question abilities, lacking experience, } \\
\text { lacking competence, lacking knowledge }\end{array}$ \\
\hline Detail Oriented & - High standards, control, controlling \\
\hline Effort & $\begin{array}{l}\text { Effort, dedicated, striving, struggling, } \\
\text { grappling }\end{array}$ \\
\hline Emotional & - Tension, angry, frustrated, relief \\
\hline Expert & - $\quad$ Expert, respected \\
\hline Overwhelmed & $\begin{array}{l}\text { Overwhelmed, stressed, pressured, } \\
\text { onslaught, mind racing, mind filled }\end{array}$ \\
\hline Pleased, Optimistic & $\begin{array}{l}\text { Pleased, optimistic, enjoy, hopeful, hope, } \\
\text { proud, honoured, excited about awards, } \\
\text { experience, people. }\end{array}$ \\
\hline Quality Oriented & - $\quad$ Concern about quality, quality control \\
\hline Worried, Concerned & $\begin{array}{l}\text { Worried, worry, concerned, anxious, } \\
\text { nervous, shaken, acutely aware, sleepless } \\
\text { night }\end{array}$ \\
\hline $\begin{array}{l}\text { Needs Representation } \\
\text { Emotional Support } \\
\text { Financial Support } \\
\text { Knowledge } \\
\text { Seeking Advice from Female Figure } \\
\text { Seeking Advice from Male Figure } \\
\text { Skills }\end{array}$ & $\begin{array}{ll}\text { - } & \text { Needing emotional support } \\
\text { - } & \text { Needing funding } \\
\text { - } & \text { Askeding information or sought advice } \\
\text { - } & \text { Asked or sought advice } \\
\text { - } & \text { Needing new skill or expertise }\end{array}$ \\
\hline
\end{tabular}




\begin{tabular}{|c|c|}
\hline $\begin{array}{l}\text { Appendix C } \\
\text { Table C3 } \\
\text { Codebook Representation of Leaders }\end{array}$ & acteristics \\
\hline Code & Description \\
\hline Leader & - $\quad$ Led a team, leads \\
\hline Credentialing & $\begin{array}{l}\text { Position title, educational experience, } \\
\text { previous work experience, awards } \\
\text { received }\end{array}$ \\
\hline Challenge & $\begin{array}{l}\text { - Challenge, difficulty, dilemma, struggle, } \\
\text { problem }\end{array}$ \\
\hline Collaboration & \\
\hline Interorganizational Collaboration & - Collaborating with another organization or \\
\hline Interpersonal Collaboration & $\begin{array}{l}\text { Collaborating with another person, } \\
\text { receiving feedback from another person }\end{array}$ \\
\hline Intraorganizational Collaboration & $\begin{array}{l}\text { - Collaborating with other departments or } \\
\text { units in an organization }\end{array}$ \\
\hline Pink Behavior & $\begin{array}{l}\text { People oriented, people interaction, } \\
\text { relationship }\end{array}$ \\
\hline $\begin{array}{l}\text { Power } \\
\text { Coercive } \\
\text { Empowers Others } \\
\text { Expert } \\
\text { Legitimate } \\
\text { Limited or No Power } \\
\text { Referent } \\
\text { Reputational } \\
\text { Reward }\end{array}$ & \\
\hline Rational, Decisive & - $\quad$ Evidence, analysis, decided, strategic \\
\hline Risk Averse & - Avoid risks \\
\hline Risk-Taking & - $\quad$ Taking risks \\
\hline
\end{tabular}

\begin{tabular}{|c|c|}
\hline $\begin{array}{l}\text { Appendix C } \\
\text { Table C4 } \\
\text { Codebook Representation of Vision }\end{array}$ & \\
\hline $\begin{array}{l}\text { Vision } \\
\text { Attributed to Female Protagonist } \\
\text { Attributed to Male Protagonist } \\
\text { Attributed to Organization }\end{array}$ & $\begin{array}{l}\text { - Goals, wants, vision, direction, values } \\
\text { - } \quad \text { Goals, wants, vision, direction, values } \\
\text { - Goals, wants, vision, direction, values }\end{array}$ \\
\hline $\begin{array}{l}\text { Visionary Characteristics } \\
\text { Innovative, Creative } \\
\text { Intuitive, Sensing } \\
\text { Passion, Dreams }\end{array}$ & $\begin{array}{l}\text { - Innovative, creative, curious, intrigued, } \\
\text { inspired, experiment, change agent } \\
\text { - Felt, feel, sensing opportunities, intuition } \\
\text { - Passion, dreams, excitement about attainment } \\
\text { of dream, enthusiasm, motivation, personal } \\
\text { commitment, meaning } \\
\text { - Experiences that shaped the desire to lead or } \\
\text { the passion for a particular choice }\end{array}$ \\
\hline
\end{tabular}


Table 1-SM

Descriptive Quotes from Cases Featuring Female Protagonists and Male Protagonists

\begin{tabular}{|c|c|c|}
\hline Variable & Female Protagonist & Male Protagonist \\
\hline \multirow[t]{2}{*}{ Rich Descriptions } & $\begin{array}{l}\text { Diana House's career included that of investor, creator, and } \\
\text { entrepreneur. After her graduation from Bond University's } \\
\text { law school in } 2009 \text {, Diana launched Tiny Devotions, an } \\
\text { intention based accessories company that became } \\
\text { successful through being first to market in North America } \\
\text { selling mala beads. (Cole and Parker) }\end{array}$ & $\begin{array}{l}\text { Jeff House graduated from London Ontario's Western } \\
\text { University in } 2007 \text { with an honors bachelor's degree in } \\
\text { health sciences. Upon graduation, House began a career } \\
\text { in real estate, successfully transacting } \$ 20 \text { million in sales } \\
\text { and } 120,000 \text { square feet of leasing in his first few years. He } \\
\text { launched House Group, Inc., an asset management } \\
\text { company with several commercial and residential } \\
\text { properties in their portfolio. Jeff also offered several real } \\
\text { estate brokerage and consulting services, with a strategic } \\
\text { focus on the development, construction, and project } \\
\text { management of properties in the city of London, Ontario, } \\
\text { Canada. (Cole and Parker) }\end{array}$ \\
\hline & $\begin{array}{l}\text { Hewings, the general manager of the Stars, was herself a } \\
\text { volunteer who devoted many hours per week to the club. } \\
\text { She had a bachelor's degree from McGill University and a } \\
\text { graduate diploma in communications from Concordia } \\
\text { University. She worked for eight years at Hour Magazine, a } \\
\text { weekly Montreal newspaper, as writer and editor. She had } \\
\text { played for both the McGill University Martlets and the Stars } \\
\text { and was appointed the team's general manager in } 2010 \text {. } \\
\text { She had also done extensive research on hockey and } \\
\text { published numerous in-depth articles about female hockey } \\
\text { for various media. (The Montreal Stars) }\end{array}$ & $\begin{array}{l}\text { The Vice ethos reflected the personality of its founders, } \\
\text { neither of whom had formal business training. Alvi had } \\
\text { been raised in Canada and the United States in a } \\
\text { household of immigrant academics from Pakistan, where } \\
\text { he was perpetually bridging the distance between the } \\
\text { South Asian culture and Islamic religion of his parents and } \\
\text { daily life in North America. He graduated from McGill } \\
\text { University in Montreal with a BA in philosophy. His } \\
\text { academic experiences included earning a failing grade in } \\
\text { feminist literature and subsequently dropping out of } \\
\text { graduate school-early indicators of his inability to } \\
\text { embrace mainstream political correctness. He had also } \\
\text { faced, and won, a personal battle overcoming substance } \\
\text { addiction. Alvi brought to Vice an edgy, hardened street } \\
\text { credibility that, combined with his cerebral, philosophical } \\
\text { view of freedom of expression and his editorial interests, } \\
\text { produced a journalistic style that routinely pushed the } \\
\text { boundaries of conventional sensibility. (Vice Media) }\end{array}$ \\
\hline
\end{tabular}




\begin{tabular}{|c|c|c|}
\hline Variable & Female Protagonist & Male Protagonist \\
\hline \multirow[t]{2}{*}{ Direct Quotations } & $\begin{array}{l}\text { "Younger workforce-folks who are just out of college-- } \\
\text { expect the workplace to have fun elements, they are full of } \\
\text { energy and want to do things that are meaningful and } \\
\text { impactful. They are also ambitious, in a hurry to get to the } \\
\text { goal and achieve success." (IBM India) }\end{array}$ & $\begin{array}{l}\text { "Our biggest competitor is water. You find decent } \\
\text { restaurants, which would use a cellulose pad; they wet and } \\
\text { mop the table before they make you sit there. The guy } \\
\text { goes, and you would find streaks on the table. I call a } \\
\text { cleaning cloth a dust redistribution device. It just makes } \\
\text { sure that whatever food is dropped on one side is crushed } \\
\text { and distributed rapidly across the whole table. So there is } \\
\text { a need to understand the actual meaning of hygiene and } \\
\text { cleaning. That which appears clean to the naked eye, may } \\
\text { not be the expected level of hygiene and cleaning." } \\
\text { (Diversey in India) }\end{array}$ \\
\hline & $\begin{array}{l}\text { "Our customers continue to love that product; we have an } \\
\text { aggressive sampling program as well. We make sure our } \\
\text { customers can try the product, whether it is our own olive } \\
\text { oil or one of our supplier's. We keep in direct contact with } \\
\text { our suppliers, so that's a relationship we value." (Jill's } \\
\text { Table) }\end{array}$ & $\begin{array}{l}\text { "The traditional advertising model for attracting } 18-34 \text { year } \\
\text { olds is broken. We realized that authentic content was the } \\
\text { way to connect and engage with the audience. We created } \\
\text { an in-house ad agency as a way to work with brands who } \\
\text { might otherwise have been cautious about working with } \\
\text { Vice. We didn't realize it at the time, but it became a way } \\
\text { for us to access large corporate budgets without } \\
\text { compromising our edgy content." (Vice Media) }\end{array}$ \\
\hline
\end{tabular}


Table 2-SM

Leading Differently Quotes from Cases Featuring Female Protagonists and Male Protagonists

\begin{tabular}{|c|c|c|}
\hline Variable & Female Protagonist & Male Protagonist \\
\hline $\begin{array}{l}\text { Working in Context } \\
\text { of Team }\end{array}$ & $\begin{array}{l}\text { As Lawrence and her team analyzed the current situation... } \\
\text { (Hustream Technologies) } \\
\text { Mielewski and her team began sharing their initial } \\
\text { formulations. (Ford Motor Company) }\end{array}$ & $\begin{array}{l}\text { Hayman and the team needed to devise a strategy. } \\
\text { (Nurturing Green) } \\
\text {...in discussions with his management team. (Bandhan } \\
\text { Microfinance) }\end{array}$ \\
\hline Attribution of Vision & $\begin{array}{l}\text { Her commitment to her original mission made her even } \\
\text { more determined to see la Vaca Independiente become } \\
\text { sustainable, both financially and socially. (La Vaca } \\
\text { Independiente) } \\
\text { She had a goal that was focused on changing the } \\
\text { stereotypes about and discrimination against disabled } \\
\text { persons in mainland China. (Dialogue in the Dark) }\end{array}$ & $\begin{array}{l}\text { How will we reach one billion people every day? Tom } \\
\text { Marting stared at the array of handouts and posters on his } \\
\text { desk, thinking of his company's big hairy audacious goal } \\
\text { (BHAG), set in } 2010 \text {, to deliver wellbeing to one billion } \\
\text { people every day. (GOJO Industries: Aiming for Global } \\
\text { Sustainability Leadership) } \\
\text { In March 2006, Lui travelled to the Skoll World Forum with } \\
\text { a delegation from the emerging non-profit community in } \\
\text { China. Rubbing shoulders with the worlds' first and most } \\
\text { ambitious social entrepreneurs3 rekindled his resolve to } \\
\text { change the world. (NPI in China: Organizing for Social } \\
\text { Good) }\end{array}$ \\
\hline Passion & $\begin{array}{l}\text { As much as the accomplishments she made over the past } \\
\text { few years were milestones of her passion and } \\
\text { perseverance (Lilgaa Property Management) } \\
\text { This is where she developed a passion for aiding the blind } \\
\text { (Dialogue in the Dark) }\end{array}$ & $\begin{array}{l}\text { Chris Mazza is articulate, intelligent, passionate (ORNGE) } \\
\text {...he is highly motivated and a passionate advocate of } \\
\text { nature. (Nurturing Green) }\end{array}$ \\
\hline $\begin{array}{l}\text { Creativity and } \\
\text { Innovation }\end{array}$ & $\begin{array}{l}\text { Fahmy's designs were considered new and unique } \\
\text { compared to other jewellery products sold in the Egyptian } \\
\text { market (Azzy Fahmy Restructuring a Successful Startup) }\end{array}$ & $\begin{array}{l}\text {...having the authority to make important business } \\
\text { decisions and being able to make more creative decisions } \\
\text { (Scuby's Enterprises) }\end{array}$ \\
\hline
\end{tabular}




\begin{tabular}{|c|c|c|}
\hline Variable & Female Protagonist & Male Protagonist \\
\hline $\begin{array}{l}\text { Creativity and } \\
\text { Innovation (Cont) }\end{array}$ & $\begin{array}{l}\text { Leung had to raise funds through innovative methods. } \\
\text { (Diamond Cab) }\end{array}$ & $\begin{array}{l}\text { Umbrella manufacturing was an unorganized business with } \\
\text { no patenting at all for the trademarks used. The most } \\
\text { commonly used trademarks at that time were moonlight, } \\
\text { sunlight, etc. To get recognition in this unorganized sector } \\
\text { of business, one had to do things differently, and so I did } \\
\text { two things: first, I came up with the completely new brand } \\
\text { name "Rhino" after the treasured animal found in the } \\
\text { Khaziranga National Park in Assam; and second, I used } \\
\text { screen printing, which was powder free and unique at that } \\
\text { time. (Manjushree Technopak Limited) }\end{array}$ \\
\hline \multirow[t]{2}{*}{$\begin{array}{l}\text { Intuition Sensing } \\
\text { and Gut Feel }\end{array}$} & $\begin{array}{l}\text { I believe in slow and steady initially, but once I feel it in my } \\
\text { gut, look out - I am going to go hard and really fast. (Jill's } \\
\text { Table) }\end{array}$ & $\begin{array}{l}\text { Marting could not help but feel that success in achieving } \\
\text { this goal (GOJO Industries) }\end{array}$ \\
\hline & $\begin{array}{l}\text { Edmonds thought that sustainability could become a key } \\
\text { differentiator in the IT hardware market, where products } \\
\text { were becoming commoditized. (WWF's Living Planet) }\end{array}$ & $\begin{array}{l}\text { Birnbaum reflected on what transpired: } \\
\text { The marketing presentation was delivered by a lawyer, } \\
\text { since there was no marketing department. I sensed doom. } \\
\text { No basic questions were answered. Things like, why aren't } \\
\text { you in the U.S.? In Russia? I told him [Birnbaum's friend], } \\
\text { 'It feels like everything is wrong, but I wouldn't know what } \\
\text { to do with it."' (SodaStream Takes on Coke and Pepsi) }\end{array}$ \\
\hline \multirow[t]{2}{*}{ Power } & $\begin{array}{l}\text { A recipient of several prestigious awards... Chaudhury was } \\
\text { also categorized as one of } 150 \text { "power women who shake } \\
\text { the world" by Newsweek (USA) in } 2011 \text { (Tehelika in Crisis) }\end{array}$ & $\begin{array}{l}\text { His reputation was among the best in the Virginia wine } \\
\text { industry (Michael Shaps Winery) }\end{array}$ \\
\hline & $\begin{array}{l}\text { Suppliers began to recognize Wilcox, appreciating her } \\
\text { culinary expertise and passion for the business. (Jill's } \\
\text { Table) }\end{array}$ & $\begin{array}{l}\text { David Branch became the fourth commissioner of the OHL } \\
\text { on September 15, } 1979 \text {. He had an array of experience } \\
\text { within junior hockey since graduating from the University of } \\
\text { Amherst, Massachusetts; he had been a member of his } \\
\text { university's hockey team and was passionate about hockey } \\
\text { in general. Along with being the commissioner of the OHL, } \\
\text { he had also served as president of the CHL since } 1996 . \\
\text { He was highly regarded within the Canadian junior hockey } \\
\text { community. (The Ontario Hockey League) }\end{array}$ \\
\hline
\end{tabular}




\begin{tabular}{|c|c|c|}
\hline Variable & Female Protagonist & Male Protagonist \\
\hline \multirow[t]{2}{*}{ Risk-Taking } & $\begin{array}{l}\text {...she decided to take a risk and develop this new } \\
\text { collection (Azzy Fahmy Restructuring a Successful Startup) }\end{array}$ & $\begin{array}{l}\text { Lehouse had a script loosely developed and, in his own } \\
\text { words, he "just went for it." (The Kinkajou Bottle Cutter) }\end{array}$ \\
\hline & $\begin{array}{l}\text { To encourage more people in need of travel, she pioneered } \\
\text { a partnership with Hong Kong Disneyland and other } \\
\text { organizations (Diamond Cab) }\end{array}$ & $\begin{array}{l}\text { Lui himself had become somewhat of a maverick in his } \\
\text { youth (NPI in China) }\end{array}$ \\
\hline \multirow[t]{2}{*}{ Risk Averse } & $\begin{array}{l}\text { Wong and Potter wanted to start the business slowly and } \\
\text { initially planned to target only the } 10 \text { emergency room } \\
\text { physicians at Highwood River Hospital (Complete Service } \\
\text { Billing) }\end{array}$ & Pfeiffer tended to be more cautious (Tokyo Jane) \\
\hline & $\begin{array}{l}\text { She understood the enormous benefits that the partnership } \\
\text { had to offer but recognized the need for a comprehensive } \\
\text { strategy to mitigate all of the associated risks (Sickkids in } \\
\text { Qatar) }\end{array}$ & \\
\hline \multirow[t]{2}{*}{$\begin{array}{l}\text { Rational, Decisive, } \\
\text { Evidence based }\end{array}$} & $\begin{array}{l}\text { Because social media platforms could be used or } \\
\text { downloaded free of cost, Ghaly thought that this would be } \\
\text { the best way to cut media costs (Azza Fahmy Online }(A))\end{array}$ & $\begin{array}{l}\text { He needed to crunch the numbers and determine which } \\
\text { choice would deliver the best returns. (Michael Shaps } \\
\text { Winery) }\end{array}$ \\
\hline & $\begin{array}{l}\text { She knew she would need a quantitative NAV analysis to } \\
\text { back up her reasoning (HudBay Minerals) }\end{array}$ & $\begin{array}{l}\text { The dream was replaced with pragmatism (The Indian } \\
\text { Greenpreneur) }\end{array}$ \\
\hline \multirow[t]{2}{*}{ Collaboration } & So I try to involve everyone (Amisha Gupta) & $\begin{array}{l}\text {...strong personal and project ties with the Chinese } \\
\text { government. (NPI in China) }\end{array}$ \\
\hline & $\begin{array}{l}\text { Leung also worked with many important strategic partners, } \\
\text { including elderly homes, disabled non-government } \\
\text { organizations, oil companies, land developers, theme park } \\
\text { operators, taxi operators and training organizations } \\
\text { (Diamond Cab) }\end{array}$ & $\begin{array}{l}\text { Another key to Hockley's success was the strong } \\
\text { relationship Smellie had built with the LCBO. He } \\
\text { considered the LCBO a valuable partner and had fostered } \\
\text { this relationship by focusing on how Hockley could best } \\
\text { help the LCBO. (Hockley Valley Brewing Co. Inc.) }\end{array}$ \\
\hline Agentic Behaviors & $\begin{array}{l}\text { Fahmy's dream of Azza Fahmy Jewellery (AFJ) becoming } \\
\text { an international jewellery brand pushed her to move } \\
\text { forward (Azza Fahmy International Expansion) }\end{array}$ & $\begin{array}{l}\text { The growth potential for a good product on such a platform } \\
\text { was obvious to Lehoux and he immediately started to think } \\
\text { about potential projects to debut on Kickstarter. (The } \\
\text { Kinkajou Bottle Cutter) }\end{array}$ \\
\hline
\end{tabular}




\begin{tabular}{|c|c|c|}
\hline Variable & Female Protagonist & Male Protagonist \\
\hline $\begin{array}{l}\text { Agentic Behaviors } \\
\text { (Cont) }\end{array}$ & $\begin{array}{l}\text { Wagoki was able to begin production with an upfront } \\
\text { investment of KSH15 million2 one year ago. Later, she } \\
\text { purchased another section of the building in which she was } \\
\text { currently operating for KSH2 million. (Helio Polymer } \\
\text { Enterprises) }\end{array}$ & $\begin{array}{l}\text { Soon after he joined, Deepankar set about making rapid } \\
\text { changes in the business model to draw in new customers } \\
\text { (Ajanta Packaging) }\end{array}$ \\
\hline \multirow[t]{2}{*}{$\begin{array}{l}\text { Leadership } \\
\text { Crucible }\end{array}$} & $\begin{array}{l}\text { In high school, Swietoniowska discovered she also had a } \\
\text { passion for fashion design. She had attended a Catholic } \\
\text { school in Mississauga, Ontario, that required students to } \\
\text { wear school uniforms. Once a month, the school held a } \\
\text { "civies day," and Swietoniowska took advantage of that day } \\
\text { to wear clothes she had made herself. Swietoniowska then } \\
\text { started designing and sewing dance costumes for herself } \\
\text { and others because she was unhappy with the style, fit and } \\
\text { comfort of the dancewear that was available in the retail } \\
\text { market. As a direct result of this experiment, } \\
\text { Swietoniowska decided to start her own dancewear } \\
\text { clothing company. (Korra Dancewear) }\end{array}$ & $\begin{array}{l}\text { As part of the management course, Grover went to Austria } \\
\text { to join a global business program at the FH Joanneum } \\
\text { University of Applied Sciences. The six-month exposure } \\
\text { was a great learning experience. His "eureka moment" } \\
\text { came one beautiful afternoon when a Croatian friend giftec } \\
\text { him with a zodiac plant from her mother's kitchen garden. } \\
\text { He discovered that there was a flourishing industry of } \\
\text { gifting plants in Austria. He wondered why giving plants } \\
\text { could not be done in India. After all, "It makes sense in our } \\
\text { country where gifting is an integral part of social } \\
\text { behaviour." (Nururing Green: The Growth Dilemma (C)). }\end{array}$ \\
\hline & $\begin{array}{l}\text { Living in a developing country and witnessing both the } \\
\text { extreme poverty and excessive wealth of the Mexican } \\
\text { population, Gutiérrez developed a strong sense of social } \\
\text { responsibility in her years as an accountant. Over time, she } \\
\text { became disillusioned with the concepts of corporate social } \\
\text { responsibility. (Fundación Bringas Hahgenbeck) }\end{array}$ & $\begin{array}{l}\text { Since childhood, Nayyar was very particular about the } \\
\text { wastage of resources and would go about making savings } \\
\text { for his family by switching off lights and fans when not in } \\
\text { use, and salvaging small pencil stubs which he would then } \\
\text { elongate with pen caps. He rarely used fresh paper } \\
\text { stationery and insisted on conserving and re-using blank } \\
\text { sides of used paper. (The Indian Greenpreneur) }\end{array}$ \\
\hline
\end{tabular}


Table 3-SM

Stereotypical Portrayal Quotes from Cases Featuring Female Protagonists and Male Protagonists

\begin{tabular}{|c|c|c|}
\hline Variable & Female Protagonist & Male Protagonist \\
\hline \multirow[t]{2}{*}{ Emotional } & $\begin{array}{l}\text { Chaudhury was "shocked, devastated and angry" on } \\
\text { reading the email (Tehelika in Crisis) }\end{array}$ & $\begin{array}{l}\text { The smile of serenity turned into a laugh of kindling joy } \\
\text { (The Indian Greenpreneur) }\end{array}$ \\
\hline & $\begin{array}{l}\text { I can't wait to rock the world - feel like l'm unstoppable } \\
\text { (Amisha Gupta) }\end{array}$ & $\begin{array}{l}\text { Menon was clearly irritated ... (Harmonizing Demand } \\
\text { Forecasting and Supply at Mahindra \& Mahindra, Ltd.) }\end{array}$ \\
\hline \multirow[t]{2}{*}{ Cautious } & $\begin{array}{l}\text {...had to be careful with the amount of business it } \\
\text { conducted. The small company could barely handle } \\
\text { producing enough for the Egyptian market, let alone for the } \\
\text { rest of the world. (Azza Fahmy International Expansion) }\end{array}$ & $\begin{array}{l}\text { Raman was cautiously optimistic about the process } \\
\text { (Customer Segmentation and Business Model Evolution at } \\
\text { Unbounce) }\end{array}$ \\
\hline & $\begin{array}{l}\text { Therefore, she must be convinced that her customers } \\
\text { would pay her in the future (Helio Polymer Enterprises) }\end{array}$ & Pfeiffer tended to be more cautious (Tokyo Jane) \\
\hline \multirow[t]{3}{*}{$\begin{array}{l}\text { Certainty and } \\
\text { Uncertainty }\end{array}$} & $\begin{array}{l}\text { Having worked in research for a long time, she knew how } \\
\text { critical it was to be flexible in the approach taken (Ford } \\
\text { Motor Company) }\end{array}$ & $\begin{array}{l}\text { In terms of a long-term plan for the league, Branch knew } \\
\text { there were a number of factors that could potentially } \\
\text { contribute to the attendance problems in certain markets. } \\
\text { (The Ontario Hockey League) }\end{array}$ \\
\hline & Leung was unsure (Diamond Cab) & \\
\hline & & $\begin{array}{l}\text { Marr was unsure whether his current Facebook budget was } \\
\text { adequate (Mackenzie \& Marr Guitars) }\end{array}$ \\
\hline \multirow[t]{2}{*}{ Ethics and Values } & $\begin{array}{l}\text { Swietoniowska hosted a charity fashion show in } 2011 \\
\text { called "Dance for Life," which was held to support local } \\
\text { homeless shelters. (Korra Dancewear) }\end{array}$ & $\begin{array}{l}\text { He felt very strongly about incorporating sustainability into } \\
\text { his winemaking (Michael Shaps Winery) }\end{array}$ \\
\hline & $\begin{array}{l}\text {...employer whose values match their own, the opportunity } \\
\text { to help make the world a better place. This quest for a job } \\
\text { with meaning is precisely what led Adrienne to WWF to } \\
\text { pursue her interest in corporate social responsibility and } \\
\text { partnerships (WWF Living Planet) }\end{array}$ & $\begin{array}{l}\text { He couldn't - and wouldn't - ignore the issues raised in } \\
\text { the media about its helicopters' medical interiors (ORNGE) }\end{array}$ \\
\hline
\end{tabular}




\begin{tabular}{|c|c|c|}
\hline Variable & Female Protagonist & Male Protagonist \\
\hline $\begin{array}{l}\text { Quality and Detail } \\
\text { Oriented }\end{array}$ & $\begin{array}{l}\text { Potter wanted to take one long last look at her business } \\
\text { plan to ensure she had prepared the projected statement of } \\
\text { earnings correctly (Complete Service Billing) } \\
\text { "Every time I went to Europe I was disappointed by the } \\
\text { quality of craftsmanship there, and felt I could do better } \\
\text { given the chance" (Azza Fahmy International Expansion) } \\
\text { Customers loved that Wilcox had done the research and } \\
\text { offered them top quality (Jill's Table) }\end{array}$ & $\begin{array}{l}\text { Deepankar swore by commitment and quality of services } \\
\text { (Ajanta Packaging) } \\
\text { Crafted his own wines with careful attention to the details o } \\
\text { fine wine industry (Michae/ Shaps Winery) }\end{array}$ \\
\hline Aggressive & $\begin{array}{l}\text { Leung demanded attitudinal and operational training for all } \\
\text { new Diamond Cab drivers (Diamond Cab) } \\
\\
\text { Chaudhury also noted that it was on her insistence that } \\
\text { Tejpal tendered an unconditional apology, a fact that was } \\
\text { further corroborated when Tejpal later mentioned that he } \\
\text { agreed to apologize due to Chaudhury's "adamantine } \\
\text { feminist principle insistence. (Tehelika in Crisis) }\end{array}$ & $\begin{array}{l}\text { Chandra was an aggressive go-getter (AGV) } \\
\text { His old tea estate network came in handy, and he } \\
\text { aggressively marketed to various tea companies across } \\
\text { India (Manjushree Technopak Limited) }\end{array}$ \\
\hline Credibility & $\begin{array}{l}\text { Angela Ahrendts would be named as her replacement. } \\
\text { Ahrendts had many years of experience within the fashion } \\
\text { industry. She previously held various senior positions, } \\
\text { including executive vice president at Liz Claiborne Inc., } \\
\text { executive vice president of Henri Bendel and president of } \\
\text { Donna Karan International. (Burberry) } \\
\text { Knowledge gained in her business analytics course (Denka } \\
\text { Chemicals) } \\
\text { It was November 2013, and Mohsen had been with } \\
\text { Harlequin for just over a year, after having completed her } \\
\text { MBA at Harvard and spending seven years in various } \\
\text { positions at Time Inc. During her early tenure at Harlequin, } \\
\text { Mohsen had assisted various business units with strategy } \\
\text { issues, mostly involving ways to adapt to the rise of e- } \\
\text { books. (Harlequin Enterprises) }\end{array}$ & $\begin{array}{l}\text { Deepankar joined Ajanta Packaging in 2005, after } \\
\text { completing his MBA at IMT Ghaziabad in India with a gold } \\
\text { medal. (Ajanta Packaging) } \\
\text {.. returning to Sudbury as chief executive officer (CEO) at } \\
\text { Sunwire Inc. in late } 2011 \text {. (The Kinkajou Bottle Cutter) }\end{array}$ \\
\hline
\end{tabular}


Case Name and Ivey Publishing Product Number

AGV: Crisis at the top. 9B14C008.

Ajanta Packaging. 9B13A049.

Amisha Gupta's first year at work. 9B14C002.

Azza Fahmy Jewellery: International expansion. 9B13M099.

Azza Fahmy Jewellery: Restructuring a successful startup. 9B13M097.

Bandhan Microfinance: Is transformation to bank status required? 9B14N019.

Burberry. 9B14A014.

Cole and Parker: Socks that start businesses. 9B14A006.

Complete service billing. 9B14M023.

Customer segmentation and business model evolution at Unbounce. 9B14A029.

Denka Chemicals. 9B14E007.

Dialogue in the dark: Social enterprise in China. 9B14M014.

Diamond Cab: An investment of a philanthropy fund. 9B13M077.

Diversey in India: The growth challenges and options. 9B13M115.

Ford Motor Company: New shades of green through soy foam. 9B13M109.

Fundación Bringas Hahgenbeck (FBH): Serving the needs of Mexican senior citizens. 9B14A005.

GOJO Industries: Aiming for global sustainability leadership. 9B13M108.

Harlequin Enterprises: Assessing e-books. 9B14M027.

Harmonizing demand forecasting and supply at Mahindra \& Mahindra, Ltd. 9B13D019.

Helio Polymer Enterprises. 9B14D002.

Hockley Valley Brewing Co. Inc. 9B14B006.

HudBay Minerals: Acquisition of Norsemont Mining. 9B14N013.

Hustream Technologies interactive video. 9B14E008.

IBM India: Localizing a global model of corporate citizenship. 9B14C020.

Jill's Table: Digitizing a retail legacy. 9B14A002.

Korra Dancewear. 9B14A011.

La Vaca Independiente: Should a social enterprise adopt a for-profit business model? 9B13C033.

Lilgaa Property Management: Property investing in Eldoret, Kenya. 9B14M043.

MacKenzie \& Marr Guitars. 9B13A038.

Manjushree Technopak Limited. 9B14M074.

Michael Shaps Winery: Evaluating the "Custom Crush" Opportunity. 9B13A027.

NPI in China: Organizing for social good. 9B13M122.

Nurturing Green: The growth dilemma (C). 9B13M081.

ORNGE: A crisis at Ontario's air ambulance service. 9B13C005.

Scuby's Enterprises: Starting a business in Ghana. 9B14M041.

Sickkids in Qatar - Responding to a request for proposal. 9B14M025.

SodaStream takes on Coke and Pepsi. 9B14M038.

Tehelika in crisis. 9B14M081 
The Indian Greenpreneur: Management of Frenemy Talent and Coopetition. 9B13C028.

The Kinkajou Bottle Cutter. 9B13A034.

The Montreal Stars. 9B14A043.

The Ontario Hockey League. 9B13A028.

Tokyo Jane. 9B14M085.

Vice Media: Competitive advantage and global expansion. 9B14M039.

WWF's living planet at work: Championed by HP. 9B14M014. 